\title{
Climate as a complex, self-regulating system
}

\section{Supplementary Information}

Roger $\mathrm{N}$ Jones and James H Ricketts

\section{S1. Methods}

The analyses presented in this SI were carried out with those in a companion paper (Jones and Ricketts, 2021) and some of the supporting information is contained in the SI for that paper. Crossreferences will be made when appropriate.

\section{S1.1. Climate model analyses}

\section{S1.1.1. Shift detection}

Shift detection was carried out using the multistep bivariate test (Ricketts, 2015;Jones and Ricketts, 2017;Ricketts and Jones, 2018;Ricketts, 2019) and an extensive assessment of its performance is provided in the accompanying SI, largely drawn from Ricketts (2019).

SST for the TEP and TWP regions was extracted from 30 coupled atmosphere-ocean GCMs from the CMIP5 database, RCP4.5 ensemble run 1 physical representation 1. This data was matched with 29 available records of GMST from JR17 and 27 estimates of equilibrium climate sensitivity (ECS) from the literature. These were analysed using the multistep bivariate test and the results are summarised in Section S2.

\section{S1.1.2. Probability testing}

The likelihood of shifts in TWP and TEP matching shifts in GMST \pm 1 year for the 29 models was calculated for no area weighting, and TEP and TWP as comprising $5.7 \%$ of the global and $14.25 \%$ of the tropical region. The method draws shift years for each model for TWP and TEP, and assess likelihood of them coinciding with the available shifts in GMST, initially over the entire 240-year period 1861-2100. There is no probability attached to the appearance of a shift or allowance for variations in forcing over time; instead, likelihoods are calculated after the fact. The procedure is: given $i$ shifts in TWP and TEP and $j$ shifts in GMST, calculate the probability of shifts 1 to $i$ coinciding with shifts 1 to $j \pm 1$ year. Given that weighting over time would result in some clustering, this procedure assumes that given shifts occur the process generating their frequency and timing is random. We also overlap TWP and TEP, treating them as one area adjusting the 3-year window if that is the case. For example, if there are 11 shifts with one overlapping by a year, the total window is 31 years. Each match retires 7 years from the total timeseries of 240 years. This procedure was 
carried out for the 29 models with available data. The outcome for observations is $p=0.049$, because some of the contributing shifts in TEP and TWP precede GMST by more than a year. The test for observations covers 1880-2018, whereas the model analyses proceed through a period of increasing forcing to around 2060. Because the causal assumption is that TWP and TEP influence GMST, the \pm 1 year window represents sampling uncertainty and the causal response is expected lie within that. However, as seen from observations the initial shift may precede that in GMST by more than a year. These probabilities are therefore calculated using simplified assumptions that are stricter than those that would be encountered if observations are held to be the rule.

\section{S1.1.3. Tracking model}

The tracking model used on observations is described in the SI of the accompanying paper (Section S2.1). The same exercise has been carried out for three models: CESM1-CAM5, NorESM1-M and MIROC-ESM. The tracking model follows the cumulative running mean for TWP to assess whether a regime shift has occurred and whether it coincides with a running six-month average above a threshold set by trial and error. Similar tracking is carried out for TEP but without the exceedance test because of the volatile nature of the TEP record. TWP acts as an accumulating heat store whereas TEP acts as a heat transfer station.

Data from ten regions was analysed: TWP, TEP, GMST, global land, global ocean, tropical ocean (20 ${ }^{\circ} \mathrm{S}-20^{\circ} \mathrm{N}, \mathrm{SH} 30-60^{\circ} \mathrm{S}, \mathrm{NH} 30-60^{\circ} \mathrm{N}, \mathrm{NH}$ land and SH land. These were selected as the ten most important regions thermodynamically based in the analyses in JR21. Step changes were assessed manually on an annual and monthly basis to pinpoint shift dates. The criteria for annual changes is $p<0.01$, but the timing of monthly changes associated with a particular date takes precedence, sometimes leading to an adjustment in the detected year.

\section{S1.1.4. Granger analysis}

A Granger regression analysis was used to perform two-way lagged regression analysis between TWP, TEP and GMST, for the three GCMs tested for tracking. The results are compared with observations in the main paper. Testing was carried out using the Real Statistics resource pack Release 6.3 (Zaiontz, 2018). Both de-stepped (stationary) and the raw data was tested, but only the results from the raw data are shown in the main paper. Using nonstationary time series invalidates $p$-values, but the f-test results are of most interest. Observations are tested in both stationary and non-stationary form in JR21, so we are confident the nonstationary results presented here represent the timing, direction and strength of warming during regime shifts.

http://www.real-statistics.com/free-download/real-statistics-resource-pack/ 


\section{S2. Results}

\section{S2.1. Multi-step bivariate tests}

The results of the error checking accompanying the MSBV results for TWP and TEP are presented in Table S1. The interpretive information for these is in Table S2 of the SI of the companion paper. The results show that TEP is overwhelmingly single, stationary. TWP contains $15 \%$ nonstationary shifts, showing more complicated behaviour. The earliest nonstationary shift in TEP is 2020, and in TWP is 1997. There are no single nonstationary shifts in TEP but TWP registers 15 in the historical period and 21 after 2020. The ANCOVA p<0.05 threshold is shown in Table S1. TEP performs slightly better than TWP, with $69 \% p<0.05$ and $61 \%$ p $<0.05$ respectively. For both, $3 \%$ of the balance of probabilities do not favour a breakpoint, while the rest do.

Table S1: Results of the analysis of data segments based on post-detection tests from 30 climate models and one set of observations ERSSTv5 for TEP and TWP. Note: this also contains observations, which are all single stationary.

\begin{tabular}{|l|l|l|r|r|}
\hline Area & Classification of Change & ANCOVA p<0.05 & Count & Totals \\
\hline TEP & Single, Stationary & Yes & 82 & \\
\hline TEP & Single, Stationary & No & 37 & 119 \\
\hline TEP & Multiple, Stationary & Yes & 1 & \\
\hline TEP & Multiple, Stationary & No & 0 & 1 \\
\hline TEP & Single, N/A & Yes & 0 & \\
\hline TEP & Single, N/A & No & 0 & 0 \\
\hline TEP & Single, Nonstationary & Yes & 3 & \\
\hline TEP & Single, Nonstationary & No & 0 & 3 \\
\hline TEP & Nonstationary & Yes & 1 & \\
\hline TEP & Nonstationary & No & 0 & 1 \\
\hline Total & & & & 124 \\
\hline TWP & Single, Stationary & Yes & 113 & \\
\hline TWP & Single, Stationary & No & 34 & 145 \\
\hline TWP & Multiple, Stationary & Yes & 25 & \\
\hline TWP & Multiple, Stationary & No & 4 & 29 \\
\hline TWP & Single, N/A & Yes & 14 & \\
\hline TWP & Single, N/A & No & 11 & 25 \\
\hline TWP & Single, Nonstationary & Yes & 25 & \\
\hline TWP & Single, Nonstationary & No & 11 & 36 \\
\hline TWP & Nonstationary & Yes & 1 & 6 \\
\hline TWP & Nonstationary & No & & 246 \\
\hline Total & & & & \\
\hline
\end{tabular}

The gradient between TWP and TEP varies widely amongst models but remains relatively constant over time as shown in Figure S1. This is a robust aspect of the heat-pump structure as is the ratio between shift size and frequency between east and west, discussed in Section 3.3.1 of the main paper. 


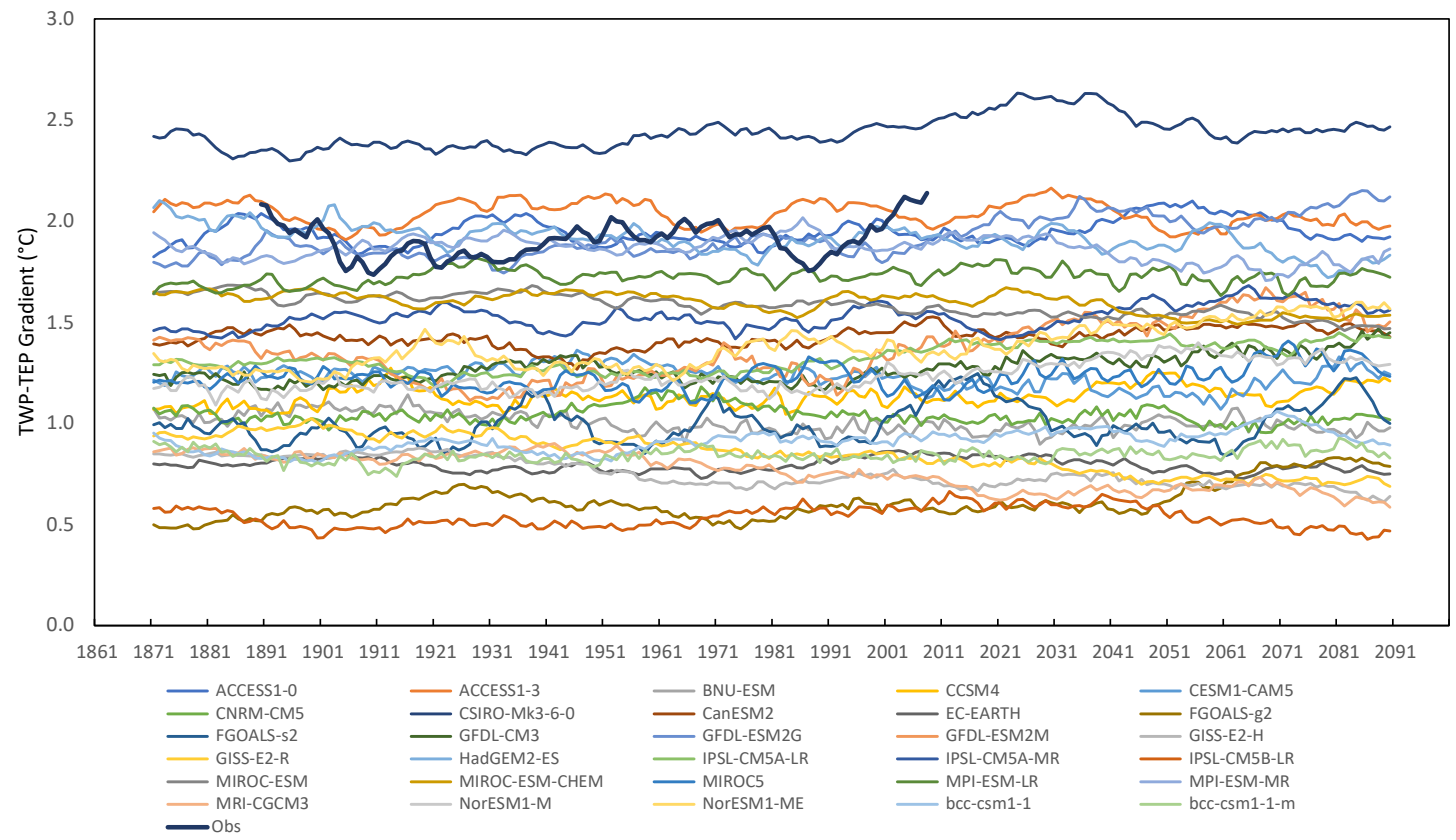

Figure S1: Gradients between TWP and TEP for 30 RCP4.5 GCMs shown with observations.

Shift-to-total-warming ratios for TEP and TWP are dominated by shifts over internal trends. Six ratios are $<0.5$ for TEP and three for TWP while in most, shifts dominate. TEP varies more widely, while the mode for TWP centres is 0.8 (Figure S3). Ratios above 1 indicates that sea surface temperatures (SST) are cooling between shifts in warming. The reduced variation within TWP is interpreted as a tighter geographic control of the warm pool by landmasses within models, whereas the placement of the core ENSO and cold tongue areas are likely to vary more widely.

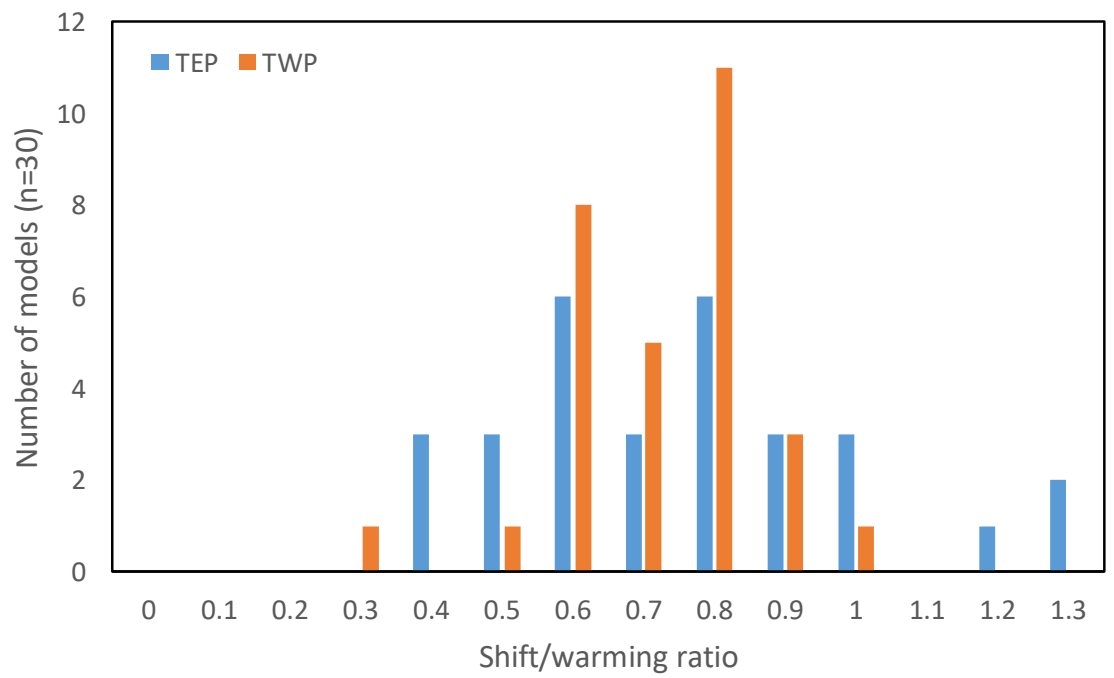

Figure S2: Distribution of shift to total warming ratios for 30 RCP4.5 GCMs for TEP and TWP. 


\section{S2.2. Relationships with GMST}

In matching shifts in TWP and TEP with GMST, the unweighted case assumes that shifts from two regions of $5.7 \%$ in global area have a direct influence on global shifts. Probabilities compared to the null case range from 0.43 to 0.0005 , averaging 0.15 and median 0.10 , with eight models under $p=0.05$. When area-weighted for the proportion of TWP or TEP in total global surface area, all results are $p<0.05$. If we assume that changes are triggered in the tropics only, the area-adjusted probabilities result in 25 of 29 models lower than observations and the $p<0.05$ threshold (Table S2). The detailed results are shown in Table S9. Table S3 shows the basic results from the average values of TEP and TWP from the model ensemble regressed to estimate ECS, based on observations.

Table S2: Probabilities of matching shifts in TEP and TWP with GMST.

\begin{tabular}{|c|c|c|c|c|c|}
\hline Model & No weighting & $\begin{array}{c}\text { Area-weighted } \\
\text { global }\end{array}$ & $\begin{array}{c}\text { Area-weighted } \\
\text { tropics }\end{array}$ & TEP average & TWP average \\
\hline ACCESS1-0 & 0.29 & 0.02 & 0.04 & 0.51 & 0.26 \\
\hline ACCESS1-3 & 0.09 & 0.01 & 0.01 & 0.65 & 0.26 \\
\hline bcc-csm1-1 & 0.26 & 0.01 & 0.04 & 0.38 & 0.21 \\
\hline bcc-csm1-1-m & 0.20 & 0.01 & 0.03 & 0.60 & 0.28 \\
\hline BNU-ESM & 0.03 & 0.00 & 0.00 & 0.70 & 0.29 \\
\hline CanESM2 & 0.007 & 0.00 & 0.00 & 0.58 & 0.31 \\
\hline CCSM4 & 0.38 & 0.02 & 0.05 & 0.49 & 0.19 \\
\hline CESM1-CAM5 & 0.12 & 0.01 & 0.02 & 0.65 & 0.24 \\
\hline CNRM-CM5 & 0.06 & 0.00 & 0.01 & 0.54 & 0.25 \\
\hline CSIRO-Mk3-6-0 & 0.04 & 0.00 & 0.01 & 0.52 & 0.44 \\
\hline EC-EARTH & 0.31 & 0.02 & 0.04 & 0.36 & 0.22 \\
\hline FGOALS-g2 & 0.43 & 0.02 & 0.06 & 0.44 & 0.20 \\
\hline GFDL-CM3 & 0.16 & 0.01 & 0.02 & 0.55 & 0.29 \\
\hline GFDL-ESM2G & 0.21 & 0.01 & 0.03 & 0.78 & 0.42 \\
\hline GFDL-ESM2M & 0.03 & 0.00 & 0.00 & 0.55 & 0.30 \\
\hline GISS-E2-H & 0.05 & 0.00 & 0.01 & 0.57 & 0.31 \\
\hline GISS-E2-R & 0.42 & 0.02 & 0.06 & 0.30 & 0.24 \\
\hline HadGEM2-ES & 0.09 & 0.01 & 0.01 & 0.29 & 0.24 \\
\hline IPSL-CM5A-LR & 0.0005 & 0.00 & 0.00 & 0.61 & 0.28 \\
\hline IPSL-CM5A-MR & 0.16 & 0.01 & 0.02 & 0.57 & 0.39 \\
\hline IPSL-CM5B-LR & 0.09 & 0.01 & 0.01 & 0.49 & 0.30 \\
\hline MIROC5 & 0.36 & 0.02 & 0.05 & 0.50 & 0.27 \\
\hline MIROC-ESM & 0.004 & 0.00 & 0.00 & 0.69 & 0.34 \\
\hline MIROC-ESM-CHEM & 0.02 & 0.00 & 0.00 & 0.36 & 0.33 \\
\hline MPI-ESM-LR & 0.03 & 0.00 & 0.00 & 0.40 & 0.32 \\
\hline MPI-ESM-MR & 0.09 & 0.01 & 0.01 & 0.70 & 0.38 \\
\hline MRI-CGCM3 & 0.28 & 0.02 & 0.04 & 0.54 & 0.32 \\
\hline NorESM1-M & 0.10 & 0.01 & 0.01 & 0.40 & 0.21 \\
\hline NorESM1-ME & 0.14 & 0.01 & 0.02 & 0.38 & 0.25 \\
\hline Average & 0.15 & 0.009 & 0.02 & 0.49 & 0.28 \\
\hline Median & 0.10 & 0.006 & 0.01 & & \\
\hline Min & 0.0005 & 0.00003 & 0.0001 & & \\
\hline Max & 0.43 & 0.025 & 0.06 & & \\
\hline Higher $p$ than observations & 21 & 0 & 4 & & \\
\hline Lower $\mathrm{p}$ than observations & 8 & 29 & 25 & & \\
\hline Less than p0.01 & 3 & 19 & 10 & & \\
\hline Less than $\mathrm{p} 0.05$ & 5 & 10 & 15 & & \\
\hline
\end{tabular}


Table S3: Regressed ECS from average TEP, TWP and joint TEP, TWP.

$\begin{array}{lcccc} & \text { Est ECS } & \text { SE } & \text { Adj } r^{2} & P \text { (f-stat) } \\ \text { TEP } & 3.2 & 0.60 & 0.30 & 0.002 \\ \text { TWP } & 3.2 & 0.67 & 0.12 & 0.05 \\ \text { Both } & 3.1 & 0.58 & 0.34 & 0.003\end{array}$

At the suggestion of a reviewer, we investigated address skill scores, which have recently become available for the CMIP5 models (Fasullo, 2020;Fasullo et al., 2020). Combining available ECS and 23 skill scores provides a sample of $n=21$ for testing. Correlations between selected variables from the model heat engine tests with the skill scores for the CMIP5 models are shown in Table S4. Some correlations are negative, associated with lower skill scores and are influenced by ECS. We divided the set into two groups above and below an ECS of $3.5^{\circ} \mathrm{C}$, summarised in Table S5. These are very small sample sizes, so correlations can be affected by one or two outliers. Full results in Table S10.

Table S4: Correlations between model skill $(n=23)$ and measures of TEP, TWP and GMST performance bolded where $p<0.05$. SWR - shift warming ratio. Note ECS $n=21$.

\begin{tabular}{|c|c|c|c|c|c|c|c|c|c|c|c|c|}
\hline & overall & energy & water & $\begin{array}{l}\text { dyna- } \\
\text { mics }\end{array}$ & annual & $\begin{array}{c}\text { seas- } \\
\text { onal }\end{array}$ & ENSO & PRW & SLP & $\begin{array}{r}\text { LWNet } \\
\text { toa }\end{array}$ & Z500 & RH500 \\
\hline ECS & 0.40 & 0.37 & 0.43 & 0.37 & 0.50 & 0.23 & 0.29 & 0.40 & 0.22 & 0.54 & 0.35 & 0.11 \\
\hline TEP av & 0.56 & 0.57 & 0.50 & 0.55 & 0.58 & 0.42 & 0.45 & 0.56 & 0.29 & 0.61 & 0.45 & 0.35 \\
\hline TWP av & -0.48 & -0.44 & -0.51 & -0.42 & -0.03 & -0.31 & -0.53 & -0.38 & -0.33 & -0.20 & -0.32 & -0.56 \\
\hline Diff & -0.02 & -0.10 & 0.06 & -0.07 & -0.19 & -0.01 & -0.02 & -0.07 & -0.05 & -0.21 & -0.12 & 0.10 \\
\hline TEP shifts & -0.75 & -0.79 & -0.71 & -0.69 & -0.53 & -0.44 & -0.74 & -0.77 & -0.52 & -0.71 & -0.59 & -0.48 \\
\hline TWP shifts & 0.21 & 0.17 & 0.15 & 0.25 & 0.11 & 0.24 & 0.15 & -0.03 & 0.11 & 0.00 & 0.28 & 0.38 \\
\hline TEP hits & -0.45 & -0.50 & -0.43 & -0.42 & -0.29 & -0.07 & -0.54 & -0.54 & -0.54 & -0.53 & -0.48 & -0.23 \\
\hline TWP hits & -0.37 & -0.47 & -0.36 & -0.31 & -0.23 & -0.24 & -0.39 & -0.44 & -0.23 & -0.32 & -0.24 & -0.26 \\
\hline TEP SWR & -0.63 & -0.69 & -0.60 & -0.49 & -0.12 & -0.32 & -0.70 & -0.65 & -0.23 & -0.49 & -0.32 & -0.56 \\
\hline TWP SWR & -0.15 & -0.26 & -0.13 & -0.06 & 0.14 & 0.08 & -0.28 & -0.27 & -0.14 & -0.08 & -0.13 & -0.02 \\
\hline GMST hits \% & -0.45 & -0.51 & -0.43 & -0.41 & -0.38 & -0.30 & -0.43 & -0.50 & -0.33 & -0.43 & -0.37 & -0.24 \\
\hline TWP\&TEP hits & -0.53 & -0.63 & -0.52 & -0.46 & -0.36 & -0.21 & -0.59 & -0.63 & -0.48 & -0.54 & -0.46 & -0.24 \\
\hline TEP/TWP ratio & -0.79 & -0.82 & -0.73 & -0.75 & -0.53 & -0.55 & -0.75 & -0.71 & -0.49 & -0.65 & -0.64 & -0.64 \\
\hline \multirow[t]{2}{*}{ TEP/TWP size } & -0.82 & -0.80 & -0.78 & -0.76 & -0.52 & -0.58 & -0.76 & -0.73 & -0.47 & -0.64 & -0.63 & -0.68 \\
\hline & $\begin{array}{r}\text { SWNet } \\
\text { toa }\end{array}$ & LH & Usfc & LWcf & Rt-Fs & $\mathbf{P}$ & E-P & SWcf & Fs & RHsfc & W500 & mean \\
\hline ECS & 0.14 & 0.46 & 0.49 & 0.51 & 0.32 & 0.37 & 0.45 & 0.21 & 0.26 & 0.00 & 0.35 & 0.34 \\
\hline TEP av & 0.38 & 0.46 & 0.48 & 0.62 & 0.56 & 0.37 & 0.42 & 0.48 & 0.38 & 0.12 & 0.53 & 0.47 \\
\hline TWP av & -0.61 & -0.40 & -0.08 & -0.16 & -0.27 & -0.52 & -0.50 & -0.55 & -0.22 & -0.01 & -0.34 & -0.35 \\
\hline Diff & 0.01 & 0.07 & -0.19 & -0.03 & -0.18 & 0.19 & 0.14 & -0.03 & -0.26 & -0.40 & -0.06 & -0.06 \\
\hline TEP shifts & -0.72 & -0.61 & -0.42 & -0.66 & -0.60 & -0.58 & -0.60 & -0.75 & -0.53 & -0.16 & -0.64 & -0.61 \\
\hline TWP shifts & 0.22 & 0.21 & 0.26 & 0.01 & 0.14 & 0.09 & 0.15 & 0.27 & 0.09 & 0.22 & 0.14 & 0.17 \\
\hline TEP hits & -0.51 & -0.33 & -0.09 & -0.43 & -0.12 & -0.40 & -0.38 & -0.45 & -0.33 & 0.00 & -0.37 & -0.37 \\
\hline TWP hits & -0.42 & -0.32 & -0.19 & -0.34 & -0.32 & -0.23 & -0.24 & -0.46 & -0.44 & -0.22 & -0.25 & -0.32 \\
\hline TEP SWR & -0.78 & -0.56 & -0.26 & -0.46 & -0.59 & -0.49 & -0.59 & -0.73 & -0.54 & 0.02 & -0.46 & -0.49 \\
\hline TWP SWR & -0.36 & -0.34 & -0.22 & -0.11 & 0.12 & -0.05 & -0.23 & -0.31 & -0.34 & 0.50 & 0.04 & -0.11 \\
\hline GMST hits \% & -0.40 & -0.39 & -0.20 & -0.40 & -0.28 & -0.33 & -0.31 & -0.47 & -0.33 & -0.15 & -0.39 & -0.37 \\
\hline TWP\&TEP hits & -0.57 & -0.48 & -0.26 & -0.50 & -0.38 & -0.38 & -0.39 & -0.57 & -0.52 & -0.14 & -0.40 & -0.44 \\
\hline TEP/TWP ratio & -0.77 & -0.67 & -0.51 & -0.61 & -0.62 & -0.59 & -0.63 & -0.83 & -0.54 & -0.23 & -0.66 & -0.64 \\
\hline TEP/TWP size & -0.77 & -0.70 & -0.52 & -0.60 & -0.65 & -0.65 & -0.70 & -0.82 & -0.51 & -0.18 & -0.69 & -0.65 \\
\hline
\end{tabular}

PRW precipitable water, SLP sea level pressure, LWNet toa, top-of-atmosphere net longwave radiation, Z500 $500 \mathrm{hPa}$ geopotential height, $500 \mathrm{hPa}$ relative humidity, LWNet toa, top-of-atmosphere net shortwave radiation, LH latent heat, Usfc surface-adjusted windspeed, LWcf cloud-forced longwave radiation, Rt-Fs total energy input toa downward minus surface upward, P precipitation, E-P evaporationprecipitation deficit, SWcf shortwave cloud forcing, Fs surface energy flux, RHsfc surface relative humidity, W500 vertical velocity at 500 hPa. SWR shift warming ratio. 
The most affected variable is TWP size, where the result is highly negative for ECS $>3.5^{\circ} \mathrm{C}$ and weak below. For the TWP-TEP difference, it is highly positive above $>3.5^{\circ} \mathrm{C}$ and weakly negative below, showing no net effect for the whole sample. The TEP shift/warming ratio (SWR) is also affected by outliers. Skill has little effect on these variables, or on the TWP SWR or number of shifts. The probabilities in Table S2 do also not correlate with skills, so are not shown. The conclusion is that the performance of these measures in TWP are not linked to model skill.

Some skill is associated with TEP, where it is positive with size and negative for the number of shifts and in both cases, slightly stronger $<3.5^{\circ} \mathrm{C}$. It is also negative for the number of matches, and this is because skill is associated with fewer numbers of TEP, so the chance of getting a match is reduced slightly. There is some suggestion that greater skill in the water cycle and longwave radiation leads to higher ECS, but less so above $3.5^{\circ} \mathrm{C}$.

This is described more fully in the main text, but the highest associations between skill and heat engine performance is between the relative frequency of TEP compared to TWP and the relative size of TWP compared to TEP. These show that the relationship between TWP and TEP is an essential part of the heat engine and that it is related to model skill.

Table S5: Summary of correlations between model skill $(n=23)$ and measures of TEP, TWP and GMST performance where $p<0.05$. SWR - shift warming ratio.

\begin{tabular}{|c|c|c|c|c|c|c|c|}
\hline Measure & $\begin{array}{c}\text { Skills } \\
\text { p }<0.05\end{array}$ & $\begin{array}{l}\text { Av } \\
\text { Corr }\end{array}$ & $\begin{array}{c}\text { Skills } \\
<3.5^{\circ} \mathrm{C}\end{array}$ & $\begin{array}{c}\text { Av } \\
\text { Corr }\end{array}$ & $\begin{array}{l}\text { Skills } \\
>3.5^{\circ} \mathrm{C}\end{array}$ & $\begin{array}{l}\text { Av } \\
\text { Corr }\end{array}$ & Result \\
\hline ECS & 7 & 0.34 & 3 & 0.45 & 0 & 0.22 & $\begin{array}{l}\text { Greater skill, lower ECS. Water cycle, latent } \\
\text { heat, geopotential height }\end{array}$ \\
\hline $\operatorname{TEP}$ av $\left({ }^{\circ} \mathrm{C}\right)$ & 17 & 0.47 & 2 & 0.45 & 0 & 0.31 & $\begin{array}{l}\text { Greater skill, higher av TEP. Some partitioning } \\
\text { by ECS each way for individual skills }\end{array}$ \\
\hline TWP av $\left({ }^{\circ} \mathrm{C}\right)$ & 10 & -0.35 & 0 & -0.20 & 15 & -0.69 & Greater skill, lower TWP. Strongly partitioned \\
\hline $\operatorname{Diff}\left({ }^{\circ} \mathrm{C}\right)$ & 0 & -0.06 & 3 & -0.39 & 14 & 0.70 & $\begin{array}{l}\text { Greater skill, higher gradient above }>3.5^{\circ} \mathrm{C} \text {, } \\
\text { lower gradient }<3.5^{\circ} \mathrm{C} \text {, no overall effect }\end{array}$ \\
\hline TEP shifts (n) & 22 & -0.61 & 14 & -0.62 & 9 & -0.56 & $\begin{array}{l}\text { Greater skill, fewer TEP shifts. Not partitioned } \\
\text { by ECS }\end{array}$ \\
\hline TWP shifts $(n)$ & 0 & 0.17 & 0 & 0.26 & 0 & 0.14 & No effect \\
\hline TEP hits ( $\mathrm{n}$ ) & 12 & -0.37 & 8 & -0.54 & 1 & -0.29 & $\begin{array}{l}\text { Greater skill, fewer matches, partitioned by } \\
<3.5^{\circ} \mathrm{C}\end{array}$ \\
\hline TWP hits (n) & 5 & -0.32 & 0 & -0.15 & 6 & -0.51 & $\begin{array}{l}\text { Greater skill, fewer matches, partitioned by } \\
>3.5^{\circ} \mathrm{C}\end{array}$ \\
\hline TEP SWR & 17 & -0.49 & 7 & -0.43 & 6 & -0.46 & $\begin{array}{l}\text { Greater skill, lower ratio, affected by low-skill } \\
\text { outliers }\end{array}$ \\
\hline TWP SWR & 1 & -0.11 & 0 & -0.11 & 1 & -0.05 & No effect \\
\hline GMST hits \% & 7 & -0.37 & 0 & -0.27 & 1 & -0.39 & $\begin{array}{l}\text { Negative for whole sample, influenced by TEP } \\
\text { result }\end{array}$ \\
\hline $\begin{array}{l}\text { TWP\&TEP hits } \\
\%\end{array}$ & 14 & -0.44 & 1 & -0.37 & 6 & -0.46 & $\begin{array}{l}\text { Negative for whole sample, partitioned by }>3.5 \\
{ }^{\circ} \mathrm{C} \text {, influenced by sample size }\end{array}$ \\
\hline $\begin{array}{l}\text { TEP/TWP } \\
\text { frequency }\end{array}$ & 22 & -0.64 & 13 & -0.67 & 9 & -0.59 & Negative for whole sample, very strong effect \\
\hline TEP/TWP size & 22 & -0.65 & 5 & -0.59 & 15 & -0.69 & $\begin{array}{l}\text { Negative for whole sample, weakly partitioned } \\
\text { by ECS }\end{array}$ \\
\hline
\end{tabular}




\section{S2.2.1. Tracking model results}

The tracking model results are shown in Plates S1-S3. They show some relationship between peaks in TWP and shifts, but not as often as for observations. The threshold value for TWP is $0.3^{\circ} \mathrm{C}$ for six months above the running mean for CESM1-CAM5 and MIROC-ESM and $0.2{ }^{\circ} \mathrm{C}$ for Nor-ESM-M. The TWP-TEP relationship is maintained throughout the sequence, with TWP leading for two models and TEP for the other, this also applies for shift initiation. Most shift sequences are initiated in in the ocean, about half in the heat engine region. More work would be needed with sampling in finer detail and numerical analysis to understand how shifts are being initiated in the models. Because the models are not as tightly coupled as observations during forced mode, their behaviour is somewhere between free and forced mode.

\section{S2.2.2. Granger analyses}

Results of the Granger analyses are shown for three periods: (1) 1880 to the first large co-ordinated shift sequence after the mid-20 $0^{\text {th }}$ century, (2) from that date to 2018 to match the observed data and (3) from the same date to 2100 . The first large shift is to mimic the free to forced response seen in observations even though the models do not show the clear transitions seen in observations.

The main types of result are:

- A large lag-1 declining effect means that last year's values strongly influence this year's outcomes.

- Lag-2 peaks means that the last two years affect this year's outcomes. Acute lag-3 is the last three years.

- Longer and trailing effects can denote behaviour such as abrupt reversals in lagged correlation (e.g., with ENSO) or complex two-way circulation.

The de-stepped results are shown in Fig. S3 and the raw results are shown in Fig. 3 of the main paper. The best result is for the influence of TEP on GMST where CESM1-CAM5 gets the shape right but is too weak. The models overemphasise the effect of TEP on TWP, which means that the twoway coupling between the two is weak and the flow from TEP to TWP too dominant.

Figure S3: Granger analyses of de-stepped (stationary) annual data for paired TWP, TEP and GMST for three climate models (1880-2100) compared to observations (1880-2018). The models are separated according to the closest date that may distinguish free from forced mode in observations. 

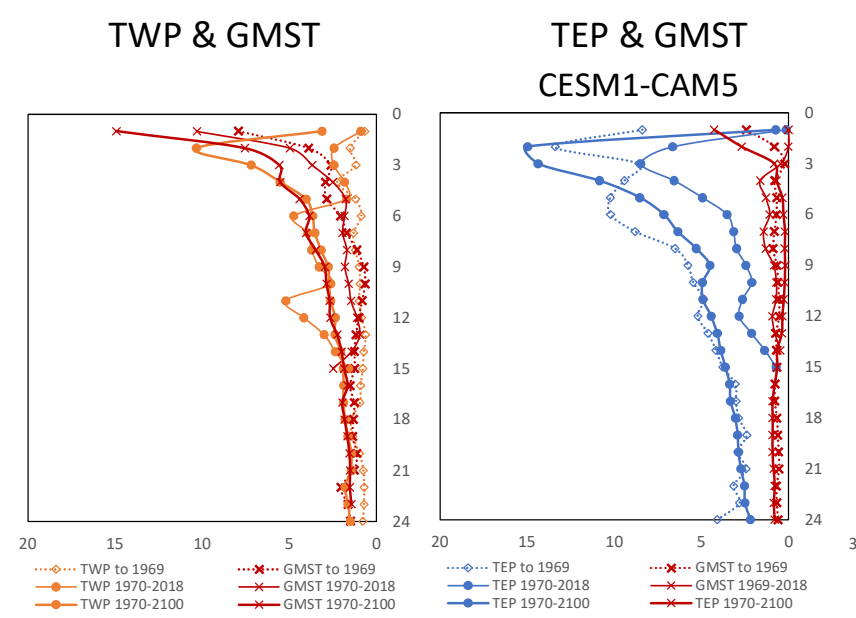

TWP \& TEP
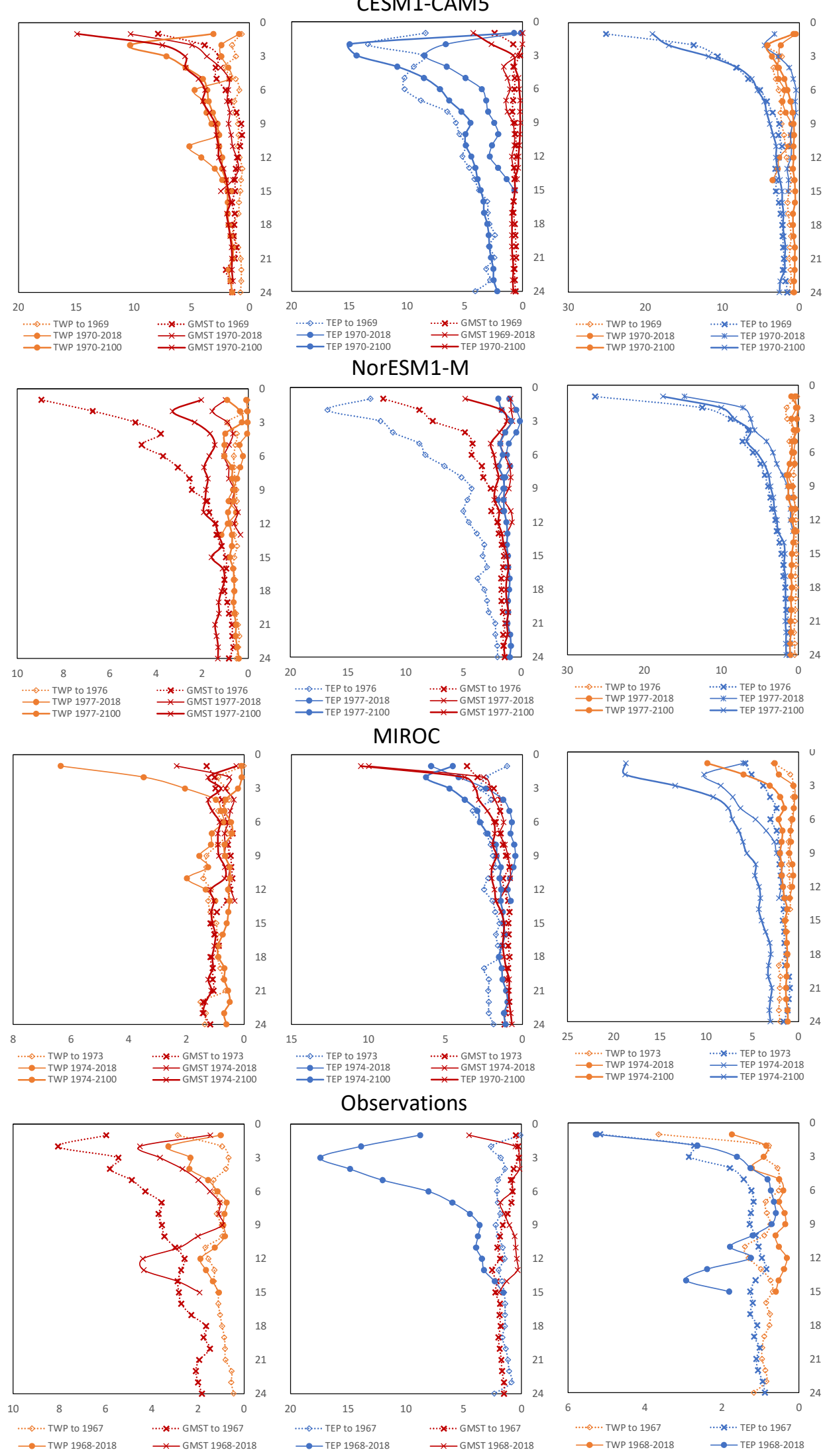


\section{S2.3. Outgoing longwave radiation}

Outgoing longwave radiation analysed for shifts includes the satellite data NOAA Interpolated Outgoing Longwave Radiation (OLR, 1979-2019) and the following reanalyses: the NCAR-NCEP Reanalysis 1 (R1 1948-2019) and NOAA/CIRES/DOE 20th Century Reanalysis (V3 1836-2015). The main paper presents tropical $\left(30^{\circ} \mathrm{S}-30^{\circ} \mathrm{N}\right)$ and extratropical comparisons, noting the large difference in interannual variability between observations and reanalyses.

Comparisons between the satellite and reanalysis data are shown in in Fig. S4 and correlations are shown in Table S6. They imply meaningful statistical relationships in some instances but some are due to an overall response to forcing. The key region of the tropics shows low correlation with the reanalyses, whereas the correlations with TEP and TWP are very high. This is due to the small area and well-understood relationships between surface heat content and outward longwave radiation. If the time series are detrended, the most naïve way to produce stationarity, most correlations either decreases or stay within \pm 0.05 (not shown). The exception is for tropical regions in the NCAR-NCEP Reanalysis 1 , partly due to their trends having opposite signs.

The global data shows an increase in 2003, which can be related to increase in specific humidity and a decrease with the change in PDO in 2015 from negative to positive (2.4 and $-1.7 \mathrm{~W} \mathrm{~m}^{-2}$ ). The is driven by a decrease in the tropics $\left(20^{\circ} \mathrm{S}-20^{\circ} \mathrm{N}\right)$, mainly in the northern part. The only other regions where observations show notable shifts are the $\mathrm{NH}$ extratropics, $30-60^{\circ} \mathrm{N}$ in $2001\left(3.1 \mathrm{~W} \mathrm{~m}^{-2}\right)$ and a minor shift in $2013(p<0.1)$ and $60-90^{\circ} \mathrm{N}$ in 2002 and $2016\left(4.2\right.$ and $\left.2.2 \mathrm{~W} \mathrm{~m}^{-2}\right)$ and $90-60^{\circ} \mathrm{S}$ in 2003 $\left(1.8 \mathrm{~W} \mathrm{~m}^{-2}\right)$. The tropical changes may be mostly decadal variability and the extratropical change can be related to changes in specific humidity (in main paper).

Table S6: Correlations between NOAA Interpolated Outgoing Longwave Radiation (1979-2019) and the NCAR-NCEP Reanalysis 1 and NOAA/CIRES/DOE 20th Century Reanalysis V3.

\begin{tabular}{|c|c|c|c|c|}
\hline Region & Obs-R1 & $p$ value & Obs-V3 & $p$ value \\
\hline Global & 0.52 & $<0.01$ & 0.35 & $<0.05$ \\
\hline $20^{\circ} \mathrm{S}-20^{\circ} \mathrm{N}$ & 0.30 & & 0.30 & \\
\hline $90-60^{\circ} \mathrm{S}$ & 0.42 & $<0.01$ & 0.34 & $<0.05$ \\
\hline $60-30^{\circ} \mathrm{S}$ & 0.49 & $<0.01$ & 0.40 & $<0.05$ \\
\hline $30-0^{\circ} \mathrm{S}$ & 0.21 & & 0.25 & \\
\hline $0-30^{\circ} \mathrm{N}$ & 0.36 & $<0.05$ & 0.09 & \\
\hline $30-60^{\circ} \mathrm{N}$ & 0.52 & $<0.01$ & 0.40 & $<0.05$ \\
\hline $60-90^{\circ} \mathrm{N}$ & 0.76 & $<0.01$ & 0.44 & $<0.01$ \\
\hline TWP & 0.74 & $<0.01$ & 0.72 & $<0.01$ \\
\hline TEP & 0.77 & $<0.01$ & 0.90 & $<0.01$ \\
\hline $30^{\circ} \mathrm{S}-30^{\circ} \mathrm{N}$ & 0.23 & & 0.11 & \\
\hline Extratropics & 0.54 & $<0.01$ & 0.49 & $<0.01$ \\
\hline
\end{tabular}


Global

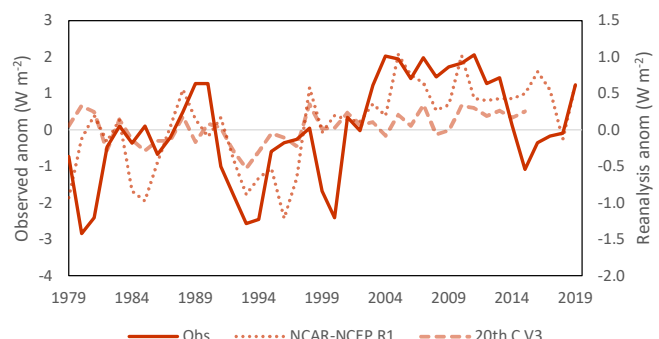

$90-60^{\circ} \mathrm{S}$

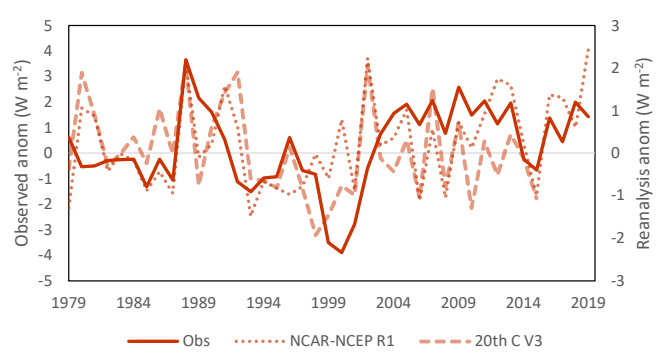

$30-0^{\circ} \mathrm{S}$

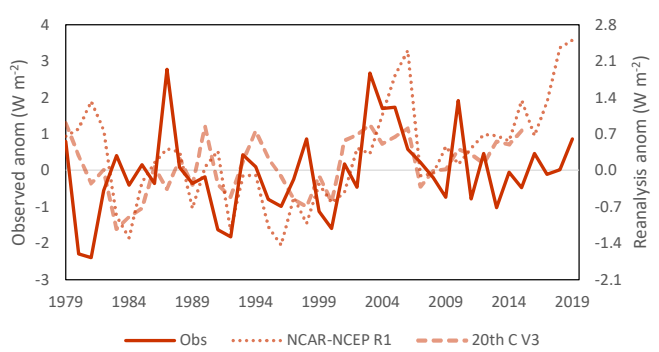

$30-60^{\circ} \mathrm{N}$

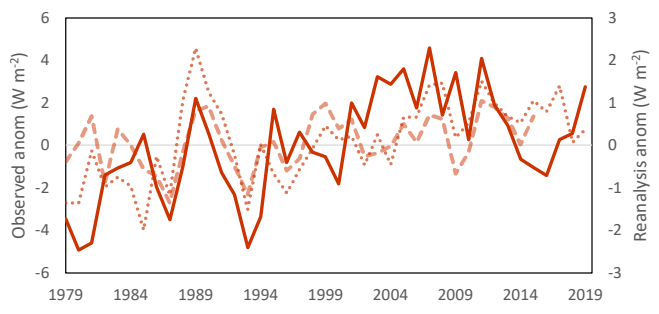

TWP

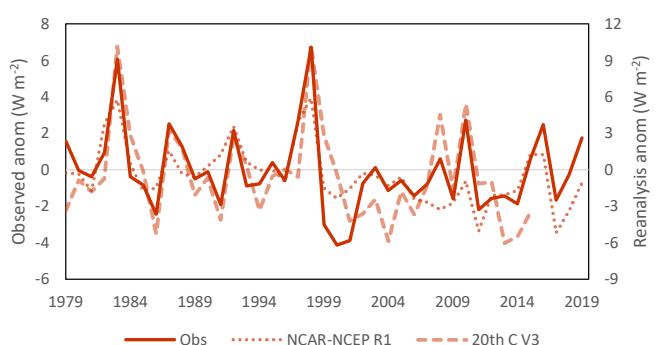

$20^{\circ} \mathrm{S}-20^{\circ} \mathrm{N}$

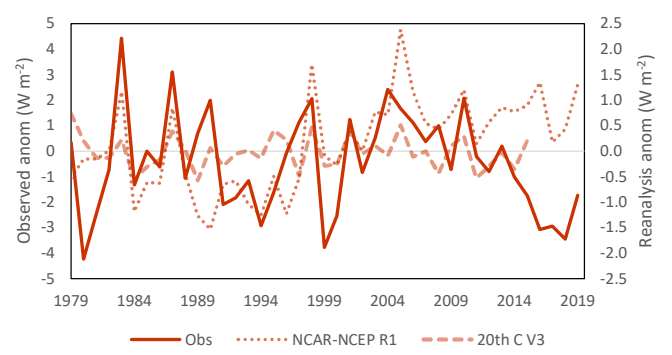

$60-30^{\circ} \mathrm{S}$

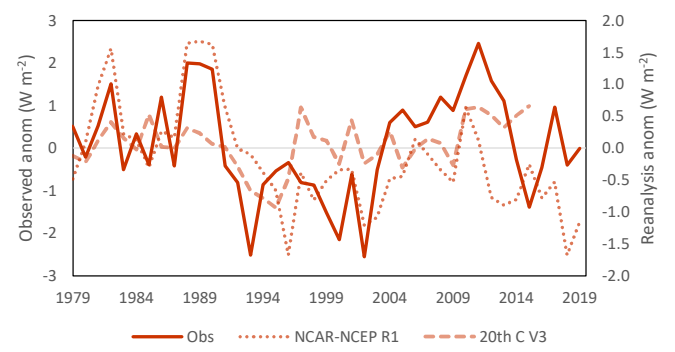

$0-30^{\circ} \mathrm{N}$

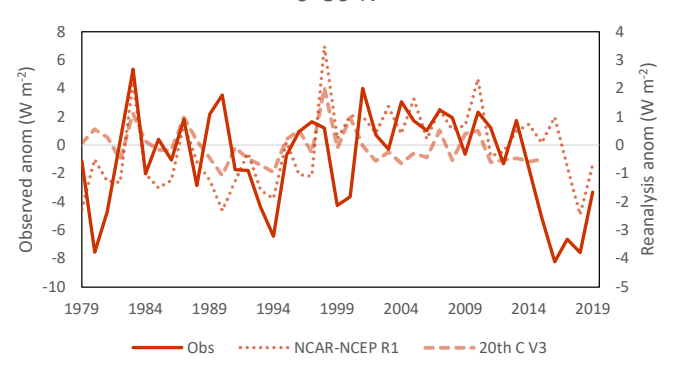

$60-90^{\circ} \mathrm{N}$

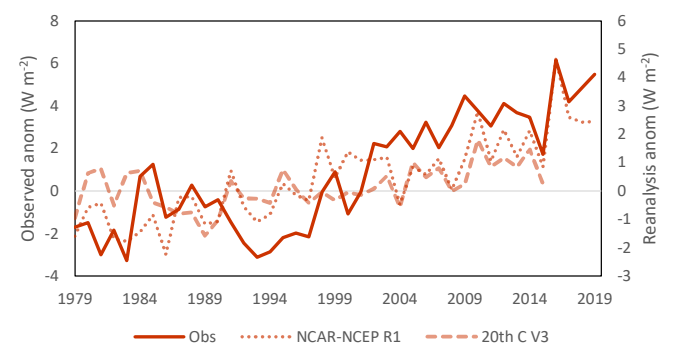

TEP

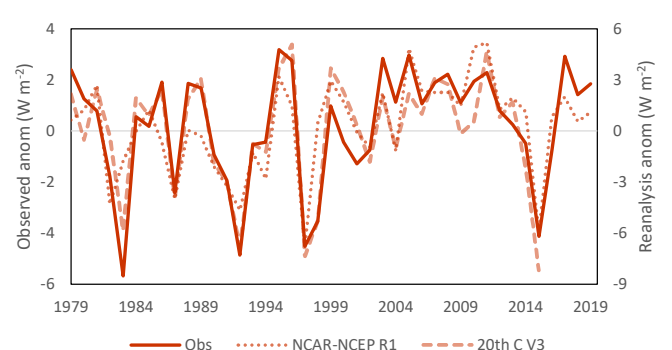

Figure S4: Comparison of observed (satellite, NOAA Interpolated Outgoing Longwave Radiation) and reanalysis (NCAR-NCEP Reanalysis 1, NOAA/CIRES/DOE 20th Century Reanalysis V3) 1979-2019 shown as a 1981-2010 anomaly for different regions. 


\section{S2.4. Specific humidity}

Table S7 shows the results of step change analysis in selected values of specific humidity from the HadIDSH data in anomalies of $\mathrm{g} \mathrm{kg}^{-1}$. In general, they follow temperature by some months but broadly coincide with the observed changes shown in JR21. Fig. S5 shows a comparison of tropical and NH ocean monthly anomalies. Each peak from 1987 to 2014 has been associated with a regime change globally or within a hemisphere.

Table S7: Regime shifts in specific humidity from the HadIDSH data 1973-2010 for major land and ocean regions. Regions are $70^{\circ} \mathrm{S}-70^{\circ} \mathrm{N}$ global, $20^{\circ}-70^{\circ}$ for the hemispheres and $20^{\circ} \mathrm{S}-20^{\circ} \mathrm{N}$ tropics.

\begin{tabular}{|l|rrrrr|}
\hline Region & \multicolumn{1}{|c}{ Ti0 } & Year & \multicolumn{1}{c}{ Shift } & Month & P value \\
\hline Global land & 9.8 & 1987 & 0.13 & May-87 & $\mathrm{p}<0.05$ \\
& 10.0 & 1997 & 0.13 & Jun-97 & $\mathrm{p}<0.05$ \\
NH Land & 9.4 & 2015 & 0.16 & Sep-15 & $\mathrm{p}<0.05$ \\
& 11.0 & 1987 & 0.14 & Nov-87 & $\mathrm{p}<0.01$ \\
& 8.8 & 1997 & 0.11 & Mar-97 & $\mathrm{p}<0.05$ \\
SH Land & 11.7 & 2015 & 0.15 & Sep-15 & $\mathrm{p}<0.01$ \\
Global ocean & $\mathrm{NR}$ & & & & \\
& 22.7 & 1994 & 0.18 & May-97 & $\mathrm{p}<0.01$ \\
NH ocean & 12.2 & 2014 & 0.16 & Jun-15 & $\mathrm{p}<0.01$ \\
& 11.7 & 1988 & 0.14 & Nov-87 & $\mathrm{p}<0.01$ \\
& 11.0 & 1994 & 0.09 & Jul-94 & $\mathrm{p}<0.01$ \\
SH ocean & 11.9 & 2014 & 0.11 & May-14 & $\mathrm{p}<0.01$ \\
Tropical ocean & 11.8 & 2015 & 0.18 & Aug-15 & $\mathrm{p}<0.01$ \\
& 16.4 & 1987 & 0.22 & Apr-87 & $\mathrm{p}<0.01$ \\
& 13.4 & 2016 & 0.29 & Jul-15 & $\mathrm{p}<0.01$ \\
\hline
\end{tabular}

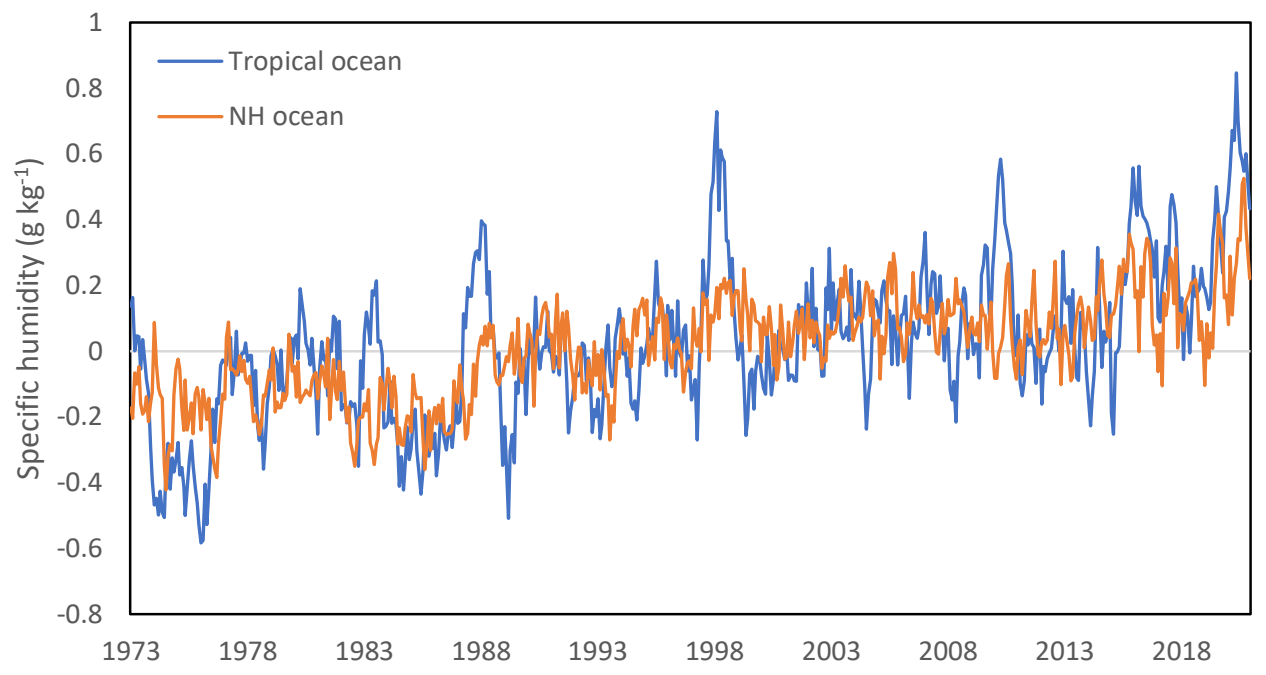

Figure S5: Comparison of specific humidity for the tropical $\left(20^{\circ} \mathrm{S}-20^{\circ} \mathrm{N}\right)$ and $\mathrm{NH}\left(20^{\circ}-70^{\circ}\right)$ oceans from the HadIDSH data in anomalies of $\mathrm{g} \mathrm{kg}^{-1}$. 


\section{S3. Data sources}

\section{S3.1. CMIP5 Climate model data}

CMIP5 RCP4.5 model GMST records were downloaded from the KNMI data explorer web site http://climexp.knmi.nl/ 7 Jan 2015. The models used in the study are in Table S8 along with ECS estimates where available. Further details are provided in the supplementary information of Jones and Ricketts (2021). SST was extracted for TEP and TWP from 30 GCMs from the Run 1 Physics 1 simulations, the initial member of each model ensemble in February 2015.

Table S8: List of modelling groups and global climate models used for simulations of 20th and 21st century climate, available from the CMIP5 database http://cmip-pcmdi.llnl.gov/cmip5/availability.html, for RCP4.5 with run numbers 1 and physics perturbations 1 with equilibrium climate sensitivity (ECS). ECS is taken from Sherwood et al. (2014) unless otherwise noted.

\begin{tabular}{|l|l|l|}
\hline Centre & Model & ECS \\
\hline BoM/CSIRO, Australia & ACCESS1-0 & 3.79 \\
BoM/CSIRO, Australia & ACCESS1-3 & 3.45 \\
Beijing Climate Center, China & BCC-CSM1-1 & 2.88 \\
Beijing Climate Center, China & BCC-CSM1-1-M & 2.90 \\
Beijing Normal University, China & BNU-ESM & 4.11 \\
Canadian Climate Centre, Canada & CanESM2 & 3.68 \\
National Center for Atmospheric Research, USA & CESM1-CAM5 & $4.10^{1}$ \\
Meteo-France, France & CNRM-CM5 & 3.25 \\
CSIRO/QCCCE, Australia & CSIRO-Mk3-6-0 & 3.99 \\
EC-Earth Consortium & EC-EARTH & 3.42 \\
LASG/Institute of Atmospheric Physics, China & FGOALS-g2 & 3.45 \\
LASG/Institute of Atmospheric Physics, China & FGOALS-s2 & 4.20 \\
Geophysical Fluid Dynamics Lab, USA & GFDL-CM3 & 3.96 \\
Geophysical Fluid Dynamics Lab, USA & GFDL-ESM2G & 2.38 \\
Geophysical Fluid Dynamics Lab, USA & GFDL-ESM2M & 2.41 \\
NASA/Goddard Institute for Space Studies, USA & GISS-E2-H & 2.30 \\
NASA/Goddard Institute for Space Studies, USA & GISS-E2-R & 2.11 \\
Met Office Hadley Centre, UK & HadGEM2-ES & 4.55 \\
Institut Pierre Simon Laplace, France & IPSL-CM5A-LR & 4.1 \\
Institut Pierre Simon Laplace, France & IPSL-CM5A-MR & \\
Institut Pierre Simon Laplace, France & IPSL-CM5B-LR & 2.59 \\
Centre for Climate Research, Japan & MIROC5 & 2.71 \\
Centre for Climate Research, Japan & MIROC-ESM & 4.65 \\
Centre for Climate Research, Japan & MIROC-ESM-CHEM & \\
Max Planck Institute for Meteorology DKRZ, Germany & MPI-ESM-LR & 3.60 \\
Max Planck Institute for Meteorology DKRZ, Germany & MPI-ESM-MR & 3.44 \\
Meteorological Research Institute, Japan & MRI-CGCM3 & 2.59 \\
Norwegian Climate Center, Norway & NorESM1-M & 2.83 \\
Norwegian Climate Center, Norway & NorESM1-ME & \\
\hline 1. Estimate from model developers (Meehl et al., 2013) & & \\
Estimate from & \\
\hline
\end{tabular}

2. Estimate from model developers (Lacagnina et al., 2014)

Additional monthly data from the KNMI data explorer was downloaded between May-June 2020. All are from data finalised in 2011 to 2012, so the download times do not affect version control. The additional data is from models CESM1-CAM5 (Neale et al., 2013), NorESM1-M (Bentsen et al., 
2013; Iversen et al., 2013) and MIROC-ESM (Watanabe et al., 2011) run1, physics 1. Regions for surface temperature downloaded include TWP, TEP, GMST, global land, global ocean, tropical ocean $\left(20^{\circ} \mathrm{S}-20^{\circ} \mathrm{N}, \mathrm{SH} 30-60^{\circ} \mathrm{S}, \mathrm{NH} 30-60^{\circ} \mathrm{N}, \mathrm{NH}\right.$ land and SH land. Additionally, selected regional and global monthly means were downloaded for top of the atmosphere short- and long-wave radiation and surface latent heat and sensible heat flux for CESM1-CAM5, and top of the atmosphere shortand long-wave radiation for NorWSM1-M.

\section{S3.2. Outgoing longwave radiation}

Data sources are NOAA Interpolated Outgoing Longwave Radiation (OLR, 1979-2019)(Lee, 2014), the NCAR-NCEP Reanalysis 1 (R1 1948-2019)(Kalnay et al., 1996) and NOAA/CIRES/DOE 20th Century Reanalysis (V3 1836-2015) (Slivinski et al., 2019).

The observed data was downloaded from the NOAA Physical Sciences Laboratory (https://psl.noaa.gov/data/gridded/data.interp OLR.html) and the NCAR-NCEP Reanalysis 1 (https://psl.noaa.gov/data/gridded/data.ncep.reanalysis.html). The $20^{\text {th }}$ Century reanalysis data was downloaded from the KNMI data explorer, and spatial averages have recently also been made available from NOAA PSL (https://psl.noaa.gov/data/gridded/data.20thC ReanV3.html). All data was downloaded in June 2020. Original data source: NOAA/OAR/ESRL PSL, Boulder, Colorado, USA.

\section{S3.3. Specific humidity}

The Hadley Centre HadISDH data set was used to investigate changes in specific humidity. The land data set is version 4.3.1.2020f (Smith et al., 2011; Willett et al., 2014) and the marine and blended data sets version 1.1.0.2020f (Willett et al., 2020). Updates to the data were downloaded in May 2021 and is the final version for the data to December 2020.

(https://www.metoffice.gov.uk/hadobs/hadisdh/). 


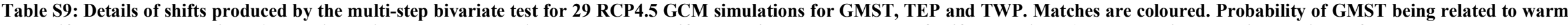

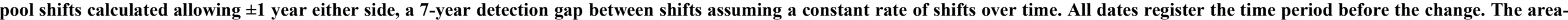
weighted probability is calculated based on the area of TWP and TEP having a global influence based on being $5.7 \%$ of global surface area.

\begin{tabular}{|c|c|c|c|}
\hline ACCESS1-3 & {$[1913,1982,2000,2007,2021,2032,2045,2057,2076,2092]$} & {$[2000,2037,2050]$} & {$[1909,1995,2006,2021,2033,2045,2052,2068]$} \\
\hline bcc-csm1-1 & {$[1919,1973,1985,1995,2006,2020,2035,2053,2074]$} & {$[1919,1987,2007,2039,2078]$} & {$[1908,1925,1972,1988,2005,2025,2038,2047,2073]$} \\
\hline BNU-ESM & {$[1883,1913,1942,1977,1994,2005,2021,2044,2057,2077]$} & {$[1947,2005,2044]$} & {$[1912,1966,1995,2013,2024,2040,2057,2078]$} \\
\hline CanESM2 & {$[1910,1976,1995,2002,2019,2028,2035,2045,2057,2074]$} & {$[1935,2002,2020,2058]$} & {$[1911,1980,2000,2020,2035,2046,2058,2076]$} \\
\hline CCSM4 & {$[1919,1974,1997,2013,2030,2042,2059,2080]$} & {$[1922,1997,2021,2058,2095]$} & {$[1883,1908,1931,1972,1997,2014,2027,2037,2058,2068,2095]$} \\
\hline CESM1-CAM5 & {$[1883,1914,1971,1997,2013,2028,2042,2053,2065,2080]$} & {$[1996,2029,2063]$} & {$[1916,1970,1997,2014,2030,2037,2051,2067,2080]$} \\
\hline EC-EARTH & {$[1907,1919,1975,1986,1997,2014,2026,2037,2052,2063,2083]$} & {$[1919,1975,1997,2017,2039,2054]$} & {$[1883,1908,1928,1976,1995,2005,2021,2040,2062,2088]$} \\
\hline FGOALS-g2 & {$[1927,1964,1977,1995,2012,2024,2035,2051,2065]$} & {$[1968,2000,2024]$} & {$[1912,1969,1988,2000,2014,2025,2036,2054]$} \\
\hline GFDL-CM3 & {$[1867,1883,1919,1933,1962,1977,1996,2008,2021,2036,2050,2066,2082]$} & {$[1996,2021,2048]$} & {$[1883,1921,1941,1963,1977,2000,2017,2038,2049,2058,2081]$} \\
\hline GFDL-ESM2G & {$[1914,1930,1984,1996,2022,2045]$} & {$[1901,1994,2045]$} & {$[1908,1973,1996,2016,2038,2050]$} \\
\hline GFDL-ESM2M & {$[1883,1893,1976,1995,2010,2027,2040,2059]$} & {$[1909,1999,2044]$} & {$[1883,1908,1976,1999,2011,2027,2050,2058]$} \\
\hline GISS-E2-H & {$[1905,1917,1932,1972,1994,2001,2014,2022,2034,2046,2056,2063,2080]$} & {$[1928,1973,2000,2012,2034,2050]$} & {$[1905,1931,1994,2014,2031,2048,2063]$} \\
\hline GISS-E2-R & {$[1924,1972,1997,2009,2023,2033,2045,2060,2094]$} & {$[1909,1973,1998,2016,2035,2063]$} & {$[1911,1962,1971,1999,2013,2022,2036,2062]$} \\
\hline MIROC5 & {$[1920,1996,2019,2036,2064]$} & {$[2002,2041]$} & {$[1906,1998,2024,2036,2068]$} \\
\hline MIROC-ESM & {$[1921,1942,1963,1975,1995,2009,2020,2033,2045,2057,2070]$} & {$[1919,1942,1995,2020,2031,2057,2071]$} & {$[1922,1974,1995,2010,2021,2031,2057]$} \\
\hline MIROC-ESM-CHEM & {$[1917,1975,1995,2007,2023,2040,2048,2055,2071,2081]$} & {$[1910,1974,2004,2024,2049,2071]$} & {$[1916,1977,2006,2023,2048,2055,2072]$} \\
\hline MPI-ESM-LR & {$[1908,1970,1997,2010,2027,2036,2061]$} & {$[1971,2010,2049]$} & {$[1881,1908,1971,1998,2010,2031,2049,2073]$} \\
\hline MPI-ESM-MR & {$[1883,1891,1919,1970,1988,1996,2006,2021,2039,2048,2073]$} & {$[1944,1996,2015,2040]$} & {$[1919,1970,1996,2007,2024,2040,2059]$} \\
\hline MRI-CGCM3 & {$[1882,1907,1933,1975,2001,2020,2037,2046,2068,2080]$} & {$[1987,2019,2043,2063]$} & {$[1883,1907,1995,2008,2025,2040,2048,2060,2068]$} \\
\hline NorESM1-M & {$[1909,1976,1998,2011,2022,2037,2056,2070,2088]$} & {$[1933,2002,2035,2059]$} & {$[1883,1910,1934,1984,1997,2018,2037,2057,2089]$} \\
\hline NorESM1-ME & {$[1923,1977,1999,2012,2026,2039,2049,2067,2083]$} & {$[2001,2045]$} & $908,1972,1998,2013,2023,2040,2050,20$ \\
\hline
\end{tabular}

$\begin{array}{ccccc}\begin{array}{c}\text { TEP \& TWP } \\ \text { matches }\end{array} & \text { TEP \& TWP } & \text { GMST } & \text { Raw } & \text { Area- } \\ 4 & 12 & \text { Shifts } & \begin{array}{c}\text { prob } \\ \text { weight }\end{array} \\ 5 & 11 & 10 & 0.29 & 0.02 \\ 5 & 14 & 9 & 0.26 & 0.01 \\ 4 & 10 & 9 & 0.20 & 0.01 \\ 6 & 11 & 10 & 0.03 & 0.002 \\ 8 & 12 & 10 & 0.01 & 0.0004 \\ 5 & 16 & 8 & 0.38 & 0.02 \\ 6 & 12 & 10 & 0.12 & 0.01 \\ 6 & 10 & 11 & 0.06 & 0.003 \\ 6 & 11 & 9 & 0.04 & 0.002 \\ 6 & 16 & 11 & 0.31 & 0.02 \\ 3 & 11 & 9 & 0.43 & 0.02 \\ 7 & 14 & 13 & 0.16 & 0.01 \\ 2 & 9 & 6 & 0.21 & 0.01 \\ 5 & 11 & 8 & 0.03 & 0.002 \\ 8 & 13 & 13 & 0.05 & 0.003 \\ 4 & 14 & 9 & 0.42 & 0.02 \\ 7 & 12 & 11 & 0.09 & 0.01 \\ 10 & 13 & 10 & 0.001 & 0.00003 \\ 7 & 16 & 10 & 0.16 & 0.01 \\ 6 & 11 & 11 & 0.09 & 0.01 \\ 1 & 7 & 5 & 0.36 & 0.02 \\ 11 & 14 & 11 & 0.004 & 0.0002 \\ 10 & 13 & 10 & 0.02 & 0.001 \\ 6 & 11 & 7 & 0.03 & 0.002 \\ 6 & 11 & 11 & 0.09 & 0.01 \\ 4 & 13 & 10 & 0.28 & 0.02 \\ 5 & 13 & 9 & 0.10 & 0.01 \\ 4 & 11 & 9 & 0.14 & 0.01\end{array}$




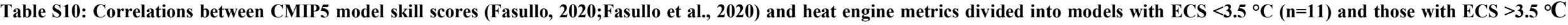
$(n=10)$. Correlations $\mathbf{p}<\mathbf{0 . 0 5}$ are shown in bold.

\begin{tabular}{|c|c|c|c|c|c|c|c|c|c|c|c|c|c|c|c|c|c|c|c|c|c|c|c|c|}
\hline & ECS & Overall & Energy & Water & Dynamics & Annual & Seasonal & ENSO & PRW & SLP & LWNet toa & Z500 & RH500 & SWNet toa & LH & Usfc & LWcf & Rt-Fs & $\mathbf{P}$ & E-P & sWcf & Fs & RHsfc & W500 \\
\hline \multirow[t]{2}{*}{$\operatorname{ECS}\left({ }^{\circ} \mathrm{C}\right)$} & $<3.5^{\circ} \mathrm{C}$ & 0.55 & 0.41 & 0.59 & 0.58 & 0.49 & 0.42 & 0.40 & 0.42 & 0.53 & 0.48 & 0.61 & 0.38 & 0.31 & 0.71 & 0.55 & 0.44 & 0.32 & 0.60 & 0.54 & 0.36 & 0.22 & 0.02 & 0.47 \\
\hline & $>3.5^{\circ} \mathrm{C}$ & 0.27 & 0.32 & 0.42 & 0.14 & 0.15 & 0.06 & 0.41 & 0.58 & -0.09 & 0.61 & -0.12 & 0.19 & 0.33 & 0.17 & 0.07 & 0.52 & 0.09 & 0.43 & 0.47 & 0.19 & -0.02 & -0.28 & 0.27 \\
\hline \multirow[t]{2}{*}{$\operatorname{TEP}$ av $\left({ }^{\circ} \mathrm{C}\right)$} & $<3.5^{\circ} \mathrm{C}$ & 0.56 & 0.45 & 0.48 & 0.61 & 0.58 & 0.54 & 0.37 & 0.50 & 0.31 & 0.48 & 0.56 & 0.53 & 0.25 & 0.46 & 0.40 & 0.57 & 0.48 & 0.39 & 0.35 & 0.43 & 0.34 & 0.17 & 0.60 \\
\hline & $>3.5^{\circ} \mathrm{C}$ & 0.40 & 0.48 & 0.34 & 0.32 & 0.21 & 0.42 & 0.37 & 0.52 & -0.10 & 0.49 & -0.15 & 0.48 & 0.49 & 0.15 & -0.01 & 0.43 & 0.54 & 0.32 & 0.23 & 0.42 & 0.26 & 0.05 & 0.45 \\
\hline \multirow[t]{2}{*}{ TWP av $\left({ }^{\circ} \mathrm{C}\right)$} & $<3.5^{\circ} \mathrm{C}$ & -0.26 & -0.34 & -0.43 & -0.01 & 0.23 & 0.31 & -0.46 & -0.43 & -0.21 & -0.18 & -0.04 & 0.02 & -0.45 & -0.45 & -0.07 & -0.21 & -0.13 & -0.30 & -0.47 & -0.34 & -0.41 & -0.12 & 0.08 \\
\hline & $>3.5^{\circ} \mathrm{C}$ & -0.89 & -0.80 & -0.86 & -0.90 & -0.75 & -0.82 & -0.79 & -0.53 & -0.47 & -0.43 & -0.68 & -0.84 & -0.85 & -0.86 & -0.56 & -0.43 & -0.59 & -0.84 & -0.85 & -0.88 & -0.65 & 0.17 & -0.87 \\
\hline \multirow[t]{2}{*}{ TWP-TEP } & $<3.5^{\circ} \mathrm{C}$ & -0.48 & -0.42 & -0.28 & -0.55 & -0.46 & -0.65 & -0.27 & -0.35 & -0.30 & -0.41 & -0.49 & -0.61 & -0.30 & -0.26 & -0.29 & -0.04 & -0.71 & -0.14 & -0.11 & -0.36 & -0.42 & -0.49 & -0.50 \\
\hline & $>3.5^{\circ} \mathrm{C}$ & 0.89 & 0.84 & 0.87 & 0.86 & 0.81 & 0.65 & 0.85 & 0.66 & 0.64 & 0.53 & 0.80 & 0.66 & 0.81 & 0.92 & 0.43 & 0.58 & 0.48 & 0.85 & 0.86 & 0.84 & 0.78 & -0.40 & 0.82 \\
\hline \multirow[t]{2}{*}{ TEP shifts (n) } & $<3.5^{\circ} \mathrm{C}$ & -0.76 & -0.73 & -0.72 & -0.70 & -0.53 & -0.55 & -0.64 & -0.74 & -0.44 & -0.62 & -0.65 & -0.63 & -0.57 & -0.66 & -0.51 & -0.58 & -0.72 & -0.55 & -0.54 & -0.72 & -0.67 & -0.41 & -0.62 \\
\hline & $>3.5^{\circ} \mathrm{C}$ & -0.71 & -0.77 & -0.67 & -0.63 & -0.56 & -0.57 & -0.71 & -0.76 & -0.25 & -0.75 & -0.23 & -0.63 & -0.72 & -0.52 & -0.04 & -0.76 & -0.58 & -0.66 & -0.57 & -0.64 & -0.63 & 0.20 & -0.73 \\
\hline \multirow[t]{2}{*}{ TWP shifts (n) } & $<3.5^{\circ} \mathrm{C}$ & 0.34 & 0.27 & 0.41 & 0.31 & 0.20 & -0.10 & 0.34 & 0.26 & 0.31 & 0.36 & 0.34 & 0.30 & 0.26 & 0.31 & -0.07 & 0.44 & -0.06 & 0.39 & 0.47 & 0.25 & 0.06 & 0.20 & 0.32 \\
\hline & $>3.5^{\circ} \mathrm{C}$ & 0.21 & 0.09 & 0.06 & 0.34 & 0.17 & 0.52 & -0.02 & -0.27 & 0.08 & -0.41 & 0.29 & 0.44 & 0.21 & 0.30 & 0.57 & -0.42 & 0.23 & 0.03 & 0.04 & 0.35 & 0.11 & 0.16 & 0.23 \\
\hline \multirow[t]{2}{*}{ TEP hits (n) } & $<3.5^{\circ} \mathrm{C}$ & -0.65 & -0.62 & -0.49 & -0.71 & -0.55 & -0.42 & -0.52 & -0.51 & -0.70 & -0.60 & -0.79 & -0.61 & -0.55 & -0.56 & -0.44 & -0.40 & -0.45 & -0.35 & -0.39 & -0.58 & -0.61 & -0.32 & -0.52 \\
\hline & $>3.5^{\circ} \mathrm{C}$ & -0.34 & -0.44 & -0.42 & -0.22 & -0.38 & 0.05 & -0.50 & -0.63 & -0.37 & -0.66 & -0.28 & 0.00 & -0.29 & -0.36 & 0.18 & -0.72 & 0.00 & -0.43 & -0.42 & -0.20 & -0.44 & 0.52 & -0.28 \\
\hline \multirow[t]{2}{*}{ TWP hits (N) } & $<3.5^{\circ} \mathrm{C}$ & -0.16 & -0.25 & -0.16 & -0.13 & -0.14 & -0.16 & -0.16 & -0.22 & -0.12 & -0.03 & -0.08 & -0.09 & -0.17 & -0.09 & -0.05 & -0.16 & -0.19 & 0.02 & 0.02 & -0.30 & -0.44 & -0.39 & -0.10 \\
\hline & $>3.5^{\circ} \mathrm{C}$ & -0.65 & -0.75 & -0.65 & -0.54 & -0.53 & -0.38 & -0.72 & -0.77 & -0.33 & -0.75 & -0.32 & -0.44 & -0.66 & -0.55 & 0.18 & -0.80 & -0.42 & -0.66 & -0.59 & -0.58 & -0.68 & 0.45 & -0.64 \\
\hline \multirow[t]{2}{*}{ TEP SWR } & $<3.5^{\circ} \mathrm{C}$ & -0.56 & -0.64 & -0.60 & -0.29 & 0.08 & 0.18 & -0.74 & -0.77 & -0.23 & -0.53 & -0.33 & -0.31 & -0.71 & -0.59 & -0.28 & -0.52 & -0.48 & -0.39 & -0.65 & -0.64 & -0.70 & -0.03 & -0.20 \\
\hline & $>3.5^{\circ} \mathrm{C}$ & -0.62 & -0.65 & -0.52 & -0.59 & -0.29 & -0.76 & -0.52 & -0.41 & 0.10 & -0.33 & -0.07 & -0.82 & -0.76 & -0.46 & -0.05 & -0.28 & -0.70 & -0.54 & -0.46 & -0.74 & -0.42 & 0.07 & -0.70 \\
\hline \multirow[t]{2}{*}{ TWP SWR } & $<3.5^{\circ} \mathrm{C}$ & -0.14 & -0.35 & -0.08 & 0.09 & 0.40 & 0.52 & -0.44 & -0.40 & -0.14 & -0.22 & -0.10 & 0.11 & -0.54 & -0.24 & -0.23 & -0.19 & -0.08 & 0.01 & -0.24 & -0.38 & -0.59 & 0.49 & 0.28 \\
\hline & $>3.5^{\circ} \mathrm{C}$ & -0.13 & -0.08 & -0.12 & -0.19 & -0.13 & -0.23 & -0.07 & -0.11 & -0.06 & 0.04 & -0.16 & -0.21 & -0.11 & -0.24 & 0.07 & -0.02 & 0.43 & -0.18 & -0.23 & -0.18 & 0.00 & 0.87 & -0.20 \\
\hline \multirow[t]{2}{*}{ GMST hits \% } & $<3.5^{\circ} \mathrm{C}$ & -0.33 & -0.34 & -0.32 & -0.33 & -0.35 & -0.46 & -0.21 & -0.26 & -0.09 & -0.21 & -0.22 & -0.30 & -0.17 & -0.18 & -0.09 & -0.18 & -0.45 & -0.22 & -0.11 & -0.36 & -0.30 & -0.46 & -0.38 \\
\hline & $>3.5^{\circ} \mathrm{C}$ & -0.49 & -0.56 & -0.47 & -0.42 & -0.54 & -0.22 & -0.54 & -0.66 & -0.46 & -0.63 & -0.38 & -0.22 & -0.41 & -0.48 & 0.10 & -0.73 & -0.06 & -0.47 & -0.42 & -0.37 & -0.60 & 0.63 & -0.46 \\
\hline \multirow[t]{2}{*}{ TEP\&TWP hits (\%) } & $<3.5^{\circ} \mathrm{C}$ & -0.43 & -0.49 & -0.37 & -0.41 & -0.33 & -0.35 & -0.38 & -0.44 & -0.34 & -0.29 & -0.39 & -0.33 & -0.39 & -0.36 & -0.31 & -0.28 & -0.46 & -0.15 & -0.17 & -0.52 & -0.66 & -0.43 & -0.31 \\
\hline & $>3.5^{\circ} \mathrm{C}$ & -0.56 & -0.67 & -0.58 & -0.42 & -0.55 & -0.15 & -0.68 & -0.77 & -0.46 & -0.82 & -0.37 & -0.20 & -0.51 & -0.52 & 0.09 & -0.88 & -0.30 & -0.57 & -0.52 & -0.41 & -0.69 & 0.37 & -0.49 \\
\hline \multirow[t]{2}{*}{ Total hits (\%) } & $<3.5^{\circ} \mathrm{C}$ & -0.83 & -0.78 & -0.81 & -0.76 & -0.56 & -0.48 & -0.72 & -0.77 & -0.52 & -0.71 & -0.73 & -0.69 & -0.63 & -0.72 & -0.45 & -0.68 & -0.66 & -0.65 & -0.67 & -0.76 & -0.64 & -0.45 & -0.68 \\
\hline & $>3.5^{\circ} \mathrm{C}$ & -0.78 & -0.77 & -0.67 & -0.78 & -0.58 & -0.87 & -0.65 & -0.57 & -0.20 & -0.46 & -0.32 & -0.89 & -0.82 & -0.62 & -0.27 & -0.45 & -0.65 & -0.66 & -0.59 & -0.83 & -0.59 & 0.19 & -0.84 \\
\hline \multirow[t]{2}{*}{$P$ values } & $<3.5^{\circ} \mathrm{C}$ & -0.74 & -0.67 & -0.77 & -0.65 & -0.47 & -0.43 & -0.65 & -0.73 & -0.38 & -0.60 & -0.59 & -0.56 & -0.53 & -0.71 & -0.45 & -0.63 & -0.63 & -0.59 & -0.63 & -0.66 & -0.59 & -0.37 & -0.61 \\
\hline & $>3.5^{\circ} \mathrm{C}$ & -0.90 & -0.85 & -0.83 & -0.89 & -0.69 & -0.89 & -0.79 & -0.66 & -0.32 & -0.53 & -0.47 & -0.93 & -0.90 & -0.75 & -0.42 & -0.51 & -0.70 & -0.82 & -0.78 & -0.91 & -0.63 & 0.18 & -0.93 \\
\hline
\end{tabular}

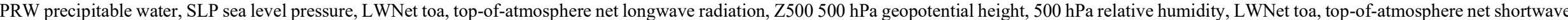

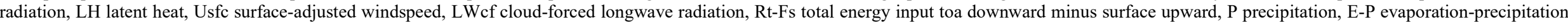
deficit, SWcf shortwave cloud forcing, Fs surface energy flux, RHsfc surface relative humidity, W500 vertical velocity at $500 \mathrm{hPa}$. SWR shift warming ratio.

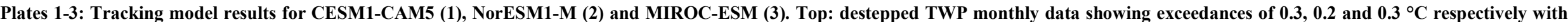

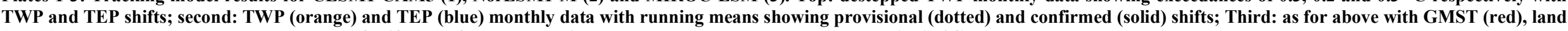
(green) and ocean (blue); Bottom: patterns of shift dates for the ten regions analysed. All measurements, anomalies in ${ }^{\circ} \mathrm{C}$. 
Plate 1 CESM-CAM5
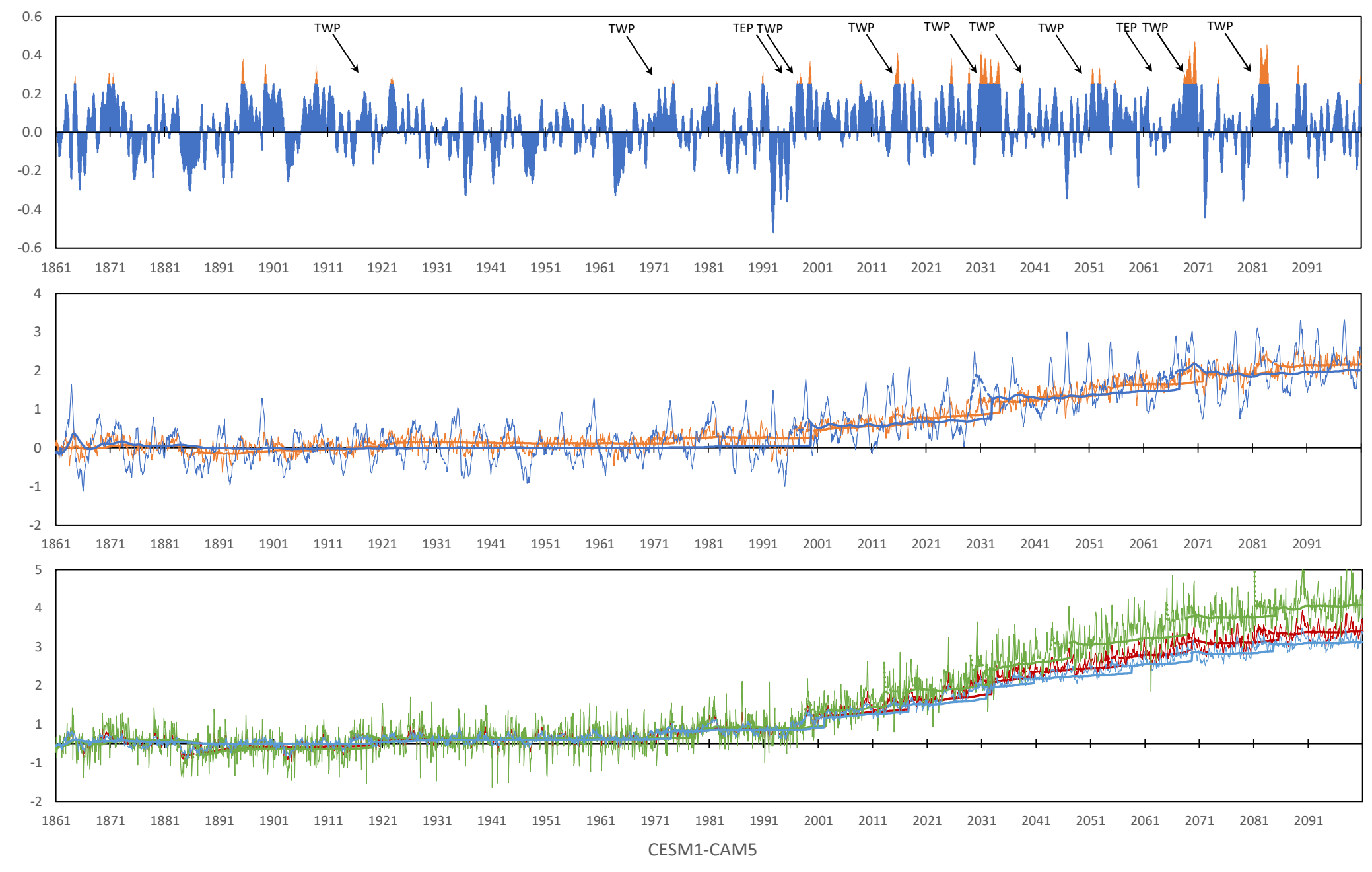

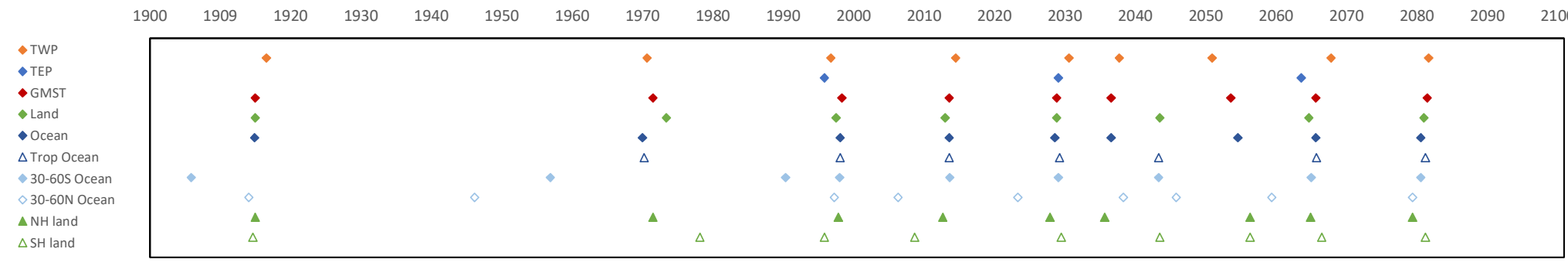


Plate 2 Nor-ESM
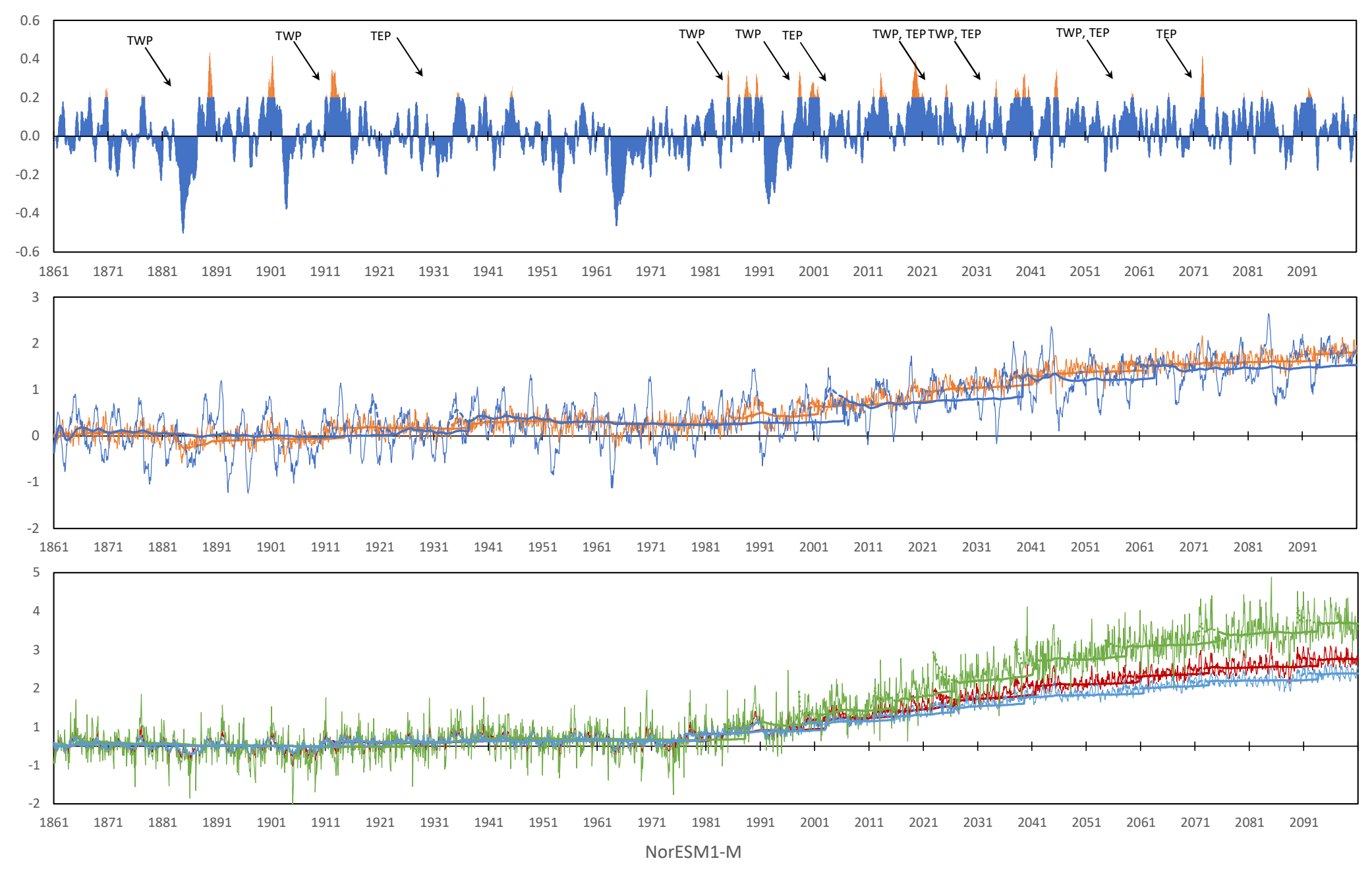

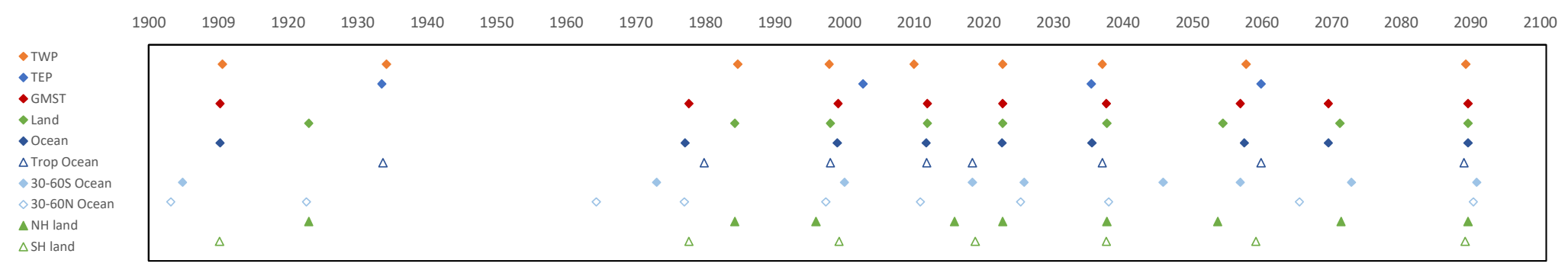



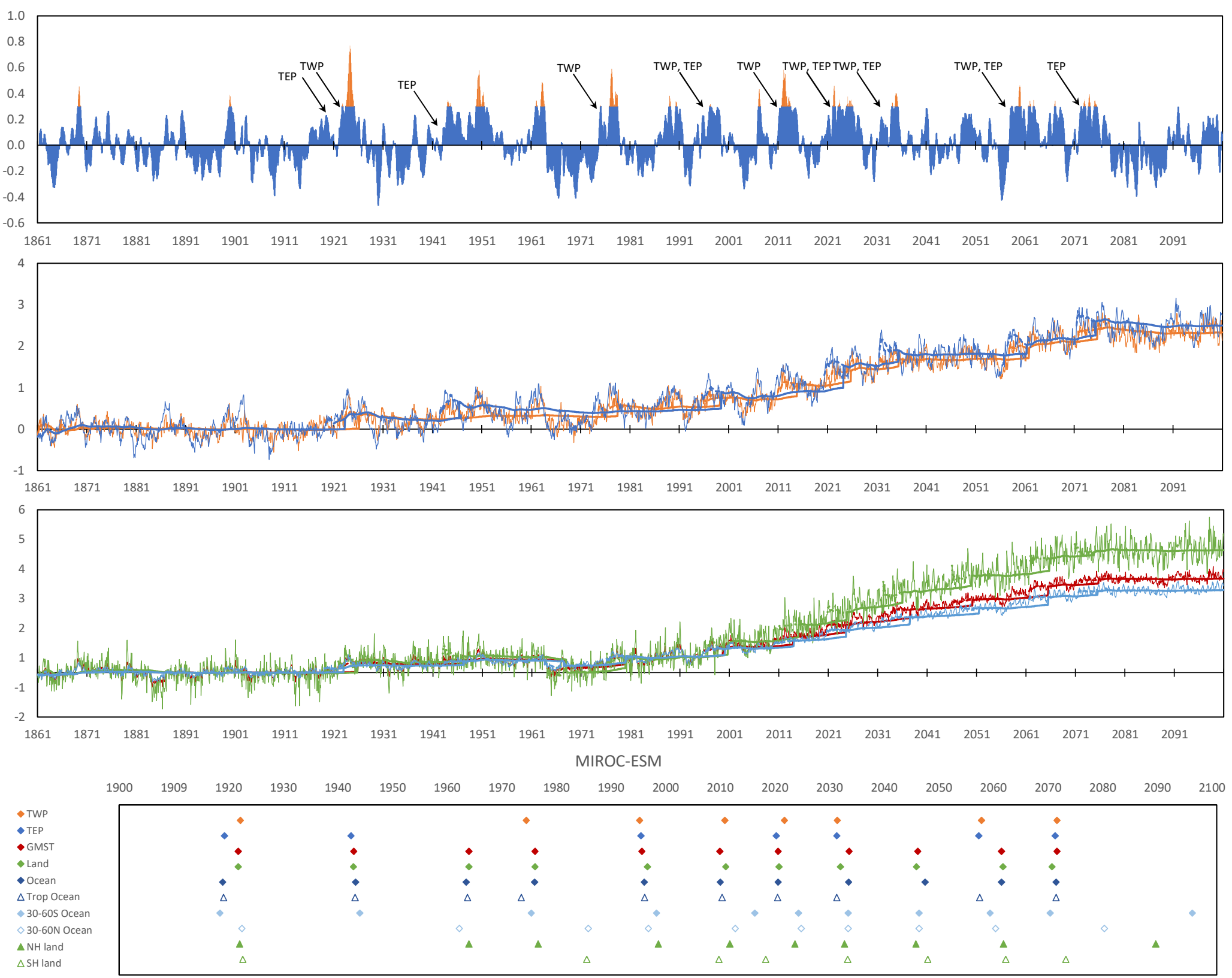


\section{References}

Bentsen, M., Bethke, I., Debernard, J. B., Iversen, T., Kirkevåg, A., Seland, $\varnothing$., Drange, H., Roelandt, C., Seierstad, I. A., and Hoose, C.: The Norwegian Earth System Model, NorESM1-M-Part 1: description and basic evaluation of the physical climate, Geosci Model Dev, 6, 687-720, 2013.

Fasullo, J. T.: Evaluating Simulated Climate Patterns from theCMIP Archives Using Satellite and Reanalysis Datasets, Geosci Model Dev Discuss, 2020, 1-26, 10.5194/gmd-2020-1, 2020.

Fasullo, J. T., Phillips, A. S., and Deser, C.: Evaluation of Leading Modes of Climate Variability in the CMIP Archives, J Clim, 33, 5527-5545, 10.1175/jcli-d-19-1024.1, 2020.

Iversen, T., Bentsen, M., Bethke, I., Debernard, J., Kirkevåg, A., Seland, $\varnothing$., Drange, H., Kristjansson, J., Medhaug, I., and Sand, M.: The Norwegian earth system model, NorESM1-M-Part 2: climate response and scenario projections, Geosci Model Dev, 6, 389-415, 2013.

Jones, R. N., and Ricketts, J. H.: Reconciling the signal and noise of atmospheric warming on decadal timescales, Earth Syst Dyn, 8, 177-210, 10.5194/esd-8-177-2017, 2017.

Jones, R. N., and Ricketts, J. H.: The Pacific Ocean heat engine, Earth Syst Dyn, submitted, 2021. Kalnay, E., Kanamitsu, M., Kistler, R., Collins, W., Deaven, D., Gandin, L., Iredell, M., Saha, S., White, G., and Woollen, J.: The NCEP/NCAR 40-year reanalysis project, Bull Am Meteorol Soc, 77, 437-472, 1996.

Lacagnina, C., Selten, F., and Siebesma, A. P.: Impact of changes in the formulation of cloud-related processes on model biases and climate feedbacks, J Adv Model Earth Syst, 6, 1224-1243, https://doi.org/10.1002/2014MS000341, 2014.

Lee, $\mathrm{H}$.: Climate algorithm theoretical basis document (C-ATBD): Outgoing longwave radiation (OLR)-Daily. NOAA's Climate Data Record (CDR) Program, 46, 2014.

Meehl, G. A., Washington, W. M., Arblaster, J. M., Hu, A., Teng, H., Kay, J. E., Gettelman, A., Lawrence, D. M., Sanderson, B. M., and Strand, W. G.: Climate Change Projections in CESM1(CAM5) Compared to CCSM4, J Clim, 26, 6287-6308, https://doi.org/10.1175/JCLI-D-12-00572.1, 2013.

Neale, R. B., Richter, J., Park, S., Lauritzen, P. H., Vavrus, S. J., Rasch, P. J., and Zhang, M.: The mean climate of the Community Atmosphere Model (CAM4) in forced SST and fully coupled experiments, J Clim, 26, 5150-5168, 2013.

Ricketts, J., and Jones, R.: Characterizing change-points in climate series with a severe approach, MODSIM2017, 22nd International Congress on Modelling and Simulation, Hobart, Tasmania, 2018. Ricketts, J. H.: A probabilistic approach to climate regime shift detection based on Maronna's bivariate test, The 21st International Congress on Modelling and Simulation (MODSIM2015), Gold Coast, Queensland, Australia, 2015.

Ricketts, J. H.: Understanding the Nature of Abrupt Decadal Shifts in a Changing Climate, Ph D (accepted under revision), Institute of Sustainable Industry and Liveable Cities, Victoria University, Melbourne, 2019.

Slivinski, L. C., Compo, G. P., Whitaker, J. S., Sardeshmukh, P. D., Giese, B. S., McColl, C., Allan, R., Yin, X., Vose, R., Titchner, H., Kennedy, J., Spencer, L. J., Ashcroft, L., Brönnimann, S., Brunet, M., Camuffo, D., Cornes, R., Cram, T. A., Crouthamel, R., Domínguez-Castro, F., Freeman, J. E., Gergis, J., Hawkins, E., Jones, P. D., Jourdain, S., Kaplan, A., Kubota, H., Blancq, F. L., Lee, T.-C., Lorrey, A., Luterbacher, J., Maugeri, M., Mock, C. J., Moore, G. W. K., Przybylak, R., Pudmenzky, C., Reason, C., Slonosky, V. C., Smith, C. A., Tinz, B., Trewin, B., Valente, M. A., Wang, X. L., Wilkinson, C., Wood, K., and Wyszyński, P.: Towards a more reliable historical reanalysis: Improvements for version 3 of the Twentieth Century Reanalysis system, Q J R Meteorolog Soc, 145, 2876-2908,

https://doi.org/10.1002/qj.3598, 2019.

Smith, A., Lott, N., and Vose, R.: The integrated surface database: Recent developments and partnerships, Bull Am Meteorol Soc, 92, 704-708, 2011.

Watanabe, S., Hajima, T., Sudo, K., Nagashima, T., Takemura, T., Okajima, H., Nozawa, T., Kawase, H., Abe, M., and Yokohata, T.: MIROC-ESM 2010: Model description and basic results of CMIP5-20c3m experiments, Geosci Model Dev, 4, 845-872, 2011. 
Willett, K., Dunn, R., Thorne, P., Bell, S., De Podesta, M., Parker, D., Jones, P., and Williams Jr, C.: HadISDH land surface multi-variable humidity and temperature record for climate monitoring, Clim Past, 10, 2014.

Willett, K. M., Dunn, R. J., Kennedy, J. J., and Berry, D. I.: Development of the HadISDH. marine humidity climate monitoring dataset, Earth Syst Sci Data, 12, 2853-2880, 2020. 